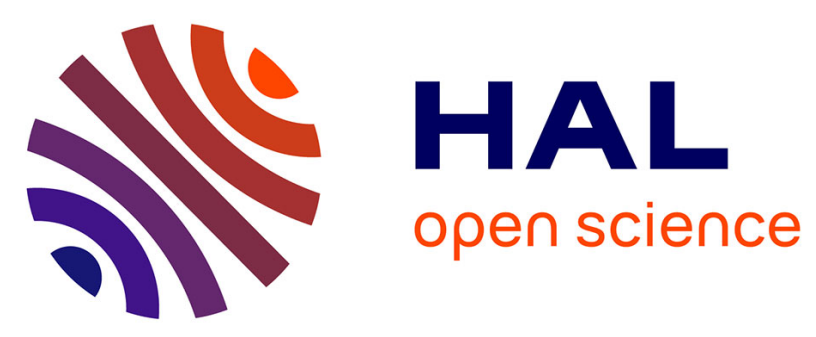

\title{
Planation surfaces of the Tian Shan Range (Central Asia): Insight on several 100 million years of topographic evolution
}

Julien Morin, Marc Jolivet, Laurie Barrier, Amandine Laborde, Haibing Li, Olivier Dauteuil

\section{To cite this version:}

Julien Morin, Marc Jolivet, Laurie Barrier, Amandine Laborde, Haibing Li, et al.. Planation surfaces of the Tian Shan Range (Central Asia): Insight on several 100 million years of topographic evolution. Journal of Asian Earth Sciences, 2019, 177, pp.52-65. 10.1016/j.jseaes.2019.03.011 . insu-02073572

HAL Id: insu-02073572

https://hal-insu.archives-ouvertes.fr/insu-02073572

Submitted on 20 Mar 2019

HAL is a multi-disciplinary open access archive for the deposit and dissemination of scientific research documents, whether they are published or not. The documents may come from teaching and research institutions in France or abroad, or from public or private research centers.
L'archive ouverte pluridisciplinaire HAL, est destinée au dépôt et à la diffusion de documents scientifiques de niveau recherche, publiés ou non, émanant des établissements d'enseignement et de recherche français ou étrangers, des laboratoires publics ou privés. 


\section{Accepted Manuscript}

Planation surfaces of the Tian Shan Range (Central Asia): Insight on several 100 million years of topographic evolution

Julien Morin, Marc Jolivet, Laurie Barrier, Amandine Laborde, Haibing Li, Olivier Dauteuil

PII:

S1367-9120(19)30122-1

DOI: https://doi.org/10.1016/j.jseaes.2019.03.011

Reference: JAES 3816

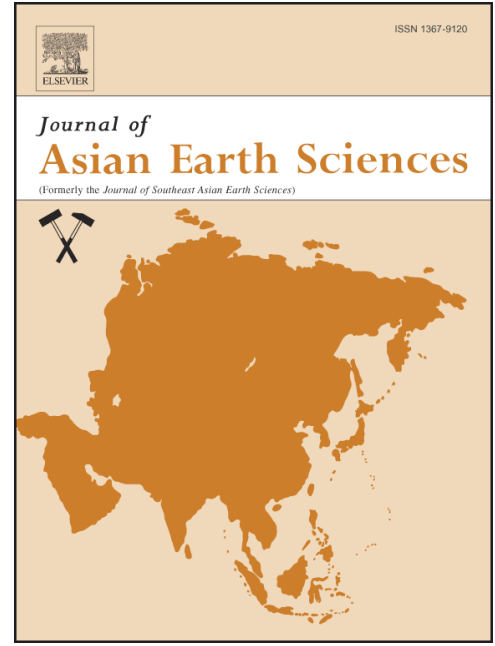

To appear in:

Journal of Asian Earth Sciences

Received Date:

9 October 2018

Revised Date:

14 March 2019

Accepted Date:

16 March 2019

Please cite this article as: Morin, J., Jolivet, M., Barrier, L., Laborde, A., Li, H., Dauteuil, O., Planation surfaces of the Tian Shan Range (Central Asia): Insight on several 100 million years of topographic evolution, Journal of Asian Earth Sciences (2019), doi: https://doi.org/10.1016/j.jseaes.2019.03.011

This is a PDF file of an unedited manuscript that has been accepted for publication. As a service to our customers we are providing this early version of the manuscript. The manuscript will undergo copyediting, typesetting, and review of the resulting proof before it is published in its final form. Please note that during the production process errors may be discovered which could affect the content, and all legal disclaimers that apply to the journal pertain. 


\title{
Planation surfaces of the Tian Shan Range (Central Asia): Insight on
}

\section{several 100 million years of topographic evolution}

Julien Morin ${ }^{1}$, Marc Jolivet ${ }^{1}$, Laurie Barrier ${ }^{2}$, Amandine Laborde ${ }^{2}$, Haibing Li ${ }^{3}$, Olivier

\section{Dauteuil $^{1}$}

${ }^{1}$ Univ Rennes, CNRS, Géosciences Rennes, UMR 6118, CNRS - F-35000 Rennes, France.

${ }^{2}$ Institut de Physique du Globe de Paris, Sorbonne Paris Cité, Université Paris Diderot, UMR 7154 CNRS, Paris, France.

${ }^{3}$ Institute of Geology, Chinese Academy of Geological Sciences, 26 Baiwanzhuang Rd., Beijing 100037, China.

\begin{abstract}
In Central Asia, numerous fragments of planation surfaces are visible within the present day topography. However, their precise timing of formations is still poorly constrained and it is not clear if they are remnants of a single extensive planation surface or if they represent different planation episodes. By reconstructing the landscape evolution of the Tian Shan region and by analyzing the relations between the planation surfaces preserved within the eastern Tarim Basin and the sedimentary record, we demonstrate that the numerous erosional surfaces preserved within the Tian Shan Range represent different episodes of surfaces genesis. These erosion events span from the late Paleozoic to the Early Cenozoic. The widespread preservation of large fragments of these surfaces within the Tian Shan Range implies that this region did not undergo strong relief building during most of its Mesozoic evolution but was dominated by plains associated to small hills along episodically active discrete tectonic structures. Finally, the preservation of these surfaces within the active Tian
\end{abstract}


Shan Range implies a long-term, strong non-equilibrium state of the topography during its Cenozoic evolution. This was probably promoted by the arid to semi-arid climate prevailing since the Late Paleogene onset of relief building.

Keywords: Tian Shan; Geomorphology; Central Asia; Topographic evolution; Planation surfaces

\section{Introduction}

Planation surfaces are of major importance for reconstructing the morphological evolution of a region, as well as its tectonic and climatic history. Indeed, the development, preservation or destruction of these surfaces are strongly linked to geodynamic cycles and climate changes (Peulevast and Sales, 2006; Calvet et al., 2015). In turn, regional to continental-scale flat lands can have a major influence on climate by preventing orographic effects or on sedimentary systems by limiting the sediment flux exported to the nearby basins. In Central Asia, planation surfaces or paleosurfaces (Widdowson, 1997) are ubiquitous within the topography, including the active ranges such as in Mongolia (De Grave et al., 2007; Jolivet et al., 2007), Siberia (De Grave and Van den haute, 2002; Jolivet et al., 2013), Tian Shan (Burbank et al., 1999; Cunningham et al., 2003; Sobel et al., 2006a; De Grave et al., 2007; Jolivet et al., 2010) or Tibet (Clark et al., 2006). They correspond to nearly flat surfaces truncating heterogeneous crystalline or sedimentary substratum of widely varying age. Dating the formation of these erosive features is a challenge. Their relative chronology is usually inferred from (1) their geometric relation with dated rocks (volcanic, plutonic or sedimentary rocks; e.g. Bessin et al., 2015), and (2) low-temperature thermochronology data constraining the timing and amplitude of major exhumation/burial events and thus providing information about the maximum or minimum age of erosional landscapes (e.g. Jolivet et al., 2007; Japsen et al., 2014). Planation surfaces can also be preserved within sedimentary basins as large 
unconformities (e.g Coltorti et al., 2007). The latest can subsequently be exhumed by stripping of the less resistant overlying sedimentary covers (e.g. Burbank et al., 1999; Sobel et al., 2006a).

In the Tian Shan area (Fig. 1), planation surfaces are widely observed and their estimated timing of genesis range from the Early Jurassic (Jolivet et al., 2010; De Grave et al., 2011) up to the Late Cretaceous - Paleogene (Cunningham et al., 2003). This very wide timing of formation throughout the region raises questions about the meaning of these surfaces in terms of continental-scale geodynamics, surface genesis and preservation. A fundamental question is thus to determine whether the planation surfaces visible within the Tian Shan region are remnants of a unique widespread surface or if they represent different planation episodes.

To address this question, we mapped the planation surfaces preserved within the Tian Shan Range and compiled both low-temperature thermochronology and stratigraphic data available for this region to constrain their age of formation. We also used seismic profiles from the eastern Tarim Basin (Fig. 1) to describe and investigate the morphological signature and geometrical relations of the buried planation surfaces preserved as unconformities within the basin. By crossing those observations in the range and the basins, we were thus able to clarify the timing of the erosional surfaces preserved within the Tian Shan area, and its implications in term of regional topographic and tectonic evolution.

\section{Geological settings}

The Tian Shan is an intracontinental range about $2000 \mathrm{~km}$ long, 200 to $400 \mathrm{~km}$ wide and up to 7400 m-high, with a landscape displaying both high mountain peaks and relatively low relief areas that often correspond to erosion-planated surfaces (Burbank et al., 1999; De Grave et al., 2007; Jolivet et al., 2010). The geological history of this mountain belt was first marked by multiple Paleozoic orogenies (e.g. Windley et al., 1990; Allen et al., 1993; Gao et al., 
1998; Gao et al., 2009; Charvet et al., 2011; Xiao et al., 2013; Alexeiev et al., 2015) subsequently followed by a complex Mesozoic evolution characterized by short-lived, low magnitude compressive to strike-slip deformations localized along major structures (Hendrix et al., 1992, 2000; Dumitru et al., 2001; Jolivet et al., 2013; Yang et al., 2015; Morin et al., 2018). Finally, a major reactivation of the Tian Shan Range occurred during the Cenozoic in response to the India-Asia collision (e.g. Tapponnier et al., 1979; Windley et al., 1990; Avouac et al., 1993a). Based on low-temperature thermochronology data (e.g. Dumitru et al., 2001; Jolivet et al., 2010; Glorie and De Grave, 2016), sediment provenance, growth strata, and sediment accommodation and accumulation rates in the northern Tarim Basin (e.g. Métivier and Gaudemer, 1997; Heermance et al., 2007, 2018), this reactivation seems to initiate by Oligocene to early Miocene.

Resulting from this long geodynamic history, the geology of the internal part of the Tian Shan Range now displays a Proterozoic-Paleozoic metamorphic and igneous basement associated to a Paleozoic-Mesozoic volcano-sedimentary and deposits and sedimentary cover (AGMCA, 2008). It also comprises Cenozoic deposits that are generally confined to a few compressive intra-mountainous basins (Fig. 1). On the other hand, the outer parts of the mountain belt present different deformation styles strongly varying from compressive structures involving the Proterozoic basement and Paleo-Cenozoic cover to fold-and-thrust belts of Paleozoic, Mesozoic and Cenozoic sediments (Carroll et al., 2001; Turner et al., 2010; Liu et al., 2016). Numerous planation surfaces are visible throughout the Tian Shan (e.g., Burbank et al., 1999; Cunningham et al., 2003; Jolivet et al., 2010; Gillepsie et al., 2017). In Kyrgyzstan, Burbank et al. (1999) described a tilted planation surface overlaid by late Oligo-Miocene sediments that they consider to have been formed after the early Mesozoic. In Chinese Tian Shan, Cunningham et al. (2003) described a tilted planation surface within the Karlik Tagh and Barkol Tagh ranges that they infer to be a remnant of a Late Cretaceous-Early Cenozoic 
peneplain without direct age constrains. However, recent low-temperature thermochronology ages obtained on this same surface rather suggest the formation of an initial surface during the Jurassic which were subsequently reworked and tilted during its Meso-Cenozoic evolution (Gillepsie et al., 2017).

Located to the south of the Tian Shan Range, the Tarim Basin corresponds to a large $\sim 1500$ $\mathrm{km}$-long and $\sim 700 \mathrm{~km}$-wide active sedimentary basin with an average surface elevation of $\sim 1200 \mathrm{~m}$ (Fig. 1). At present, the Tarim is an endorheic compressive basin completely surrounded by mountain ranges. Its stratigraphy is characterized by a Proterozoic basement composed by igneous rocks, overlain by a thick (up to $16 \mathrm{~km}$ ), more or less continuous series of Neoproterozoic (Sinian) to Quaternary sediments (Li et al., 1996; Chen and Shi, 2003; Jin et al., 2003; Wei et al., 2013; Zhang et al., 2013; Liu et al., 2016). In this sedimentary series, seismic profiles and well data document large unconformities, which show that large-scale erosion surfaces developed in this basin at different stages of its evolution (Chen and Shi., 2003; Lin et al., 2012; Lin et al., 2015; He et al., 2016; Liu et al., 2016).

\section{Methods}

\section{1. Planation surfaces in the range}

In order to identify, locate and characterize the planation surfaces in the study area, we first mapped them in the range. For this, we analyzed satellite images (Landsat, Spot and DigitalGlobe images available through the database Google Earth and DEM data (SRTM3, SRTM1 with a resolution from 90 to $30 \mathrm{~m}$ ), especially through, shading and slope maps to identify areas of low relief (Fig. 2). We also used topographic and swath profiles that represent a $2 \mathrm{D}$ vision on maximal, minimal and average altitudes of the topography within a given rectangular area. Finally, field observations and geological maps (1: 200 000/1: 500 000) helped us to distinguish between low-relief areas due to erosional surfaces exposing 
truncation of heterogeneous crystalline or sedimentary substratum from those sealed by younger sediment deposits (Fig. 2).

To better understand the timing of formation and the preservation through time of the planation surfaces identified in the range, we also reconstructed the landscape evolution of the studied region by compiling geological observations, cooling histories inferred from lowtemperature thermochronology data, and stratigraphic records available in the literature. Lowtemperature thermochronology data indeed constrain the timing and amplitude of major exhumation/burial events and thus provide information on relief development (Fig. 3) (e.g., Jolivet, 2017). Exhumation is defined as the upward displacement of a rock relative to the Earth surface and results in cooling of this rock as it moves to shallower depths (England and Molnar, 1990; Reiners and Brandon, 2006). Exhumation is generally the result of denudation processes such as tectonic and/or erosion leading to the superficial removal of rock and soil (Reiners and Brandon, 2006). Both exhumation and denudation are related to the rock and surface uplifts, which contribute to the topography building of mountain ranges when erosion is slower than rock uplift (England and Molnar, 1990). Therefore, tectonic activity can induce rapid exhumation of basement rocks, generally leading to relief development and thus, to a fast cooling period (Fig. 3). When tectonic activity decreases, the newly formed unbalanced topography then undergoes erosion leading to a lowering of the previously established relief (Fig. 3). In contrast, a period of slow cooling rates is more generally linked to low denudation (e.g. Jolivet et al., 2007; De Grave et al., 2011; Glorie and De Grave, 2016). Ultimately, a period of thermal stability must correspond to a phase where no exhumation or burial is identified within the method's resolution. This lack of vertical movements can thus be associated with a period of largely flat topography (Fig. 3). Finally, tectonic reactivation can occur leading to renewed exhumation and to reworking of the flattened relief (Fig. 3). 


\section{2. Planation surfaces in the basin}

Sedimentary basins can also record the topographic and tectonic evolution of a region. Indeed, they can preserve erosional surfaces as angular unconformities within their stratigraphic record providing information on the genesis and duration of these topographies. Therefore, in addition to the planation surfaces mapped in the Tian Shan Range, we investigated the morphological signature of the various erosional surfaces buried in the Tarim Basin and their geometrical relations with the sedimentary deposits.

In order to identify, localize and characterize the angular unconformities (i.e. the erosion surfaces) in this basin, we first gathered the studies that were previously published about its sedimentary filling. Indeed, numerous data and interpretations were already available such as (1) regional and local geological maps (e.g., Turner et al., 2010), (2) stratigraphical columns and geological cross-sections from outcrop analyses and seismic profiles (e.g., Desheng et al., 1996; Yin et al., 1998; Allen et al., 1999; Burchfield et al., 1999; Jin et al., 2008; Turner et al., 2010; Wang et al., 2013; Liu et al., 2016), and (3) isopach and isobath maps (e.g., Li et al., 1996; Yang et al., 2002; Chen et al., 2003).

In addition to the previously-published works, we then used seismic profiles and well data from the eastern Tarim Basin provided by the Sinopec Group of the China Petrochemical Corporation (Fig. 1). First, we identified the faults based on offsets of the seismic reflectors. Then, we picked several horizons along the cross-lines and in-lines through the whole seismic grid. The selected horizons were the base of the Sinian (i.e. the basement-sedimentary cover boundary in the Tarim Basin) and of the Triassic, Jurassic, and Cenozoic deposits. Intermediate reflectors were also used when they presented significant geometrical characteristics, such as unconformities with underlying toplaps and overlying onlaps. The 
ages of these horizons were mainly constrained by published and unpublished biostratigraphical datings on core samplings collected in boreholes existing in the area.

In a basin adjacent to a mountain belt, a period of tectonic activity with relief building in the range can be registered either by a contemporaneous ongoing sedimentation due to a high subsidence and sediment flux, or an angular unconformity if the uplifting and eroding area reaches the basin (Fig. 3). In contrast, a period of tectonic quiescence and flattening of the topography in the range will rather correspond to a condensed sedimentation or a hiatus and unconformity in the basin due to a limited subsidence and sediment supply (Fig. 3). In that case, no exhumation or burial will be identified within the thermochronology method resolution. Finally, a tectonic reactivation can occur leading to a new ongoing sedimentation or to the exhumation and reworking of the previous unconformities (e.g. erosive surfaces) buried below the sediments depending on the contemporaneous vertical movement in the basin.

\section{Geological evolution, stratigraphy and geomorphology of the Tian Shan Range}

\section{1. Kyrgyz Tian Shan}

\section{1. 1. The Song-Kul region}

The Song-Kul region is located at the junction between the Northern and Middle Kyrgyz Tian Shan (Figs. 1 and 4). The Northern Tian Shan (NTS) terrane consists predominantly of a Precambrian continental crust largely intruded by early Paleozoic granitoids and by early Permian post-collisional granite plutons (Konopelko et al., 2008; Glorie et al., 2010). In this region, the Middle Tian Shan (MTS) terrane consists mainly of a Precambrian microcontinent including Neoproterozoic volcanic rocks, overlain by Devonian to Carboniferous passive margin sediments (Alexeiev et al., 2016; Kröner et al., 2017). Permian collisional and post- 
collisional magmatic rocks were also emplaced within the MTS (Konopelko et al., 2007; De Grave et al., 2011; 2013).

In the Song-Kul region, numerous flat-surfaces cross-cutting Paleozoic rocks are visible within the present-day topography (Figs. 2C, 4). They are generally horizontal, sometimes incised by rivers. To the east the Song-Kul Lake, a Permian granite (293Ma U/Pb age; De Grave et al., 2011) is cross-cut by an erosional surface locally mantled by Neogene to Quaternary sediments (Figs. 4, 5) (Tursungaziev and Petrov, 2008). This constrains the development of this surface between the Permian and the Neogene. Slightly to the west, the Ming-Kush Basin displays Jurassic, Paleogene and Neogene series (De Pelsmaeker et al., 2018) that can be considered as a lateral equivalent of the sediments preserved in the SongKul Basin. The Jurassic series are $100 \mathrm{~m}$ to $680 \mathrm{~m}$ thick and rest unconformably on the Paleozoic basement (Kuzichkina, 1972; De Pelsmaeker et al., 2018). The Jurassic deposits are unconformably overlaid by ca $150 \mathrm{~m}$ of Paleocene to early Oligocene fine-grained sediments presenting numerous $\mathrm{dm}$ - to $\mathrm{m}$-thick caliche beds indicating very low Paleogene sedimentation rates within this area (De Pelsmaeker et al., 2018). Finally, the Paleogene series are unconformably covered by hundreds of meters thick Oligo-Miocene conglomerates (Lasovskiy and Mozolev, 1961; De Pelsmaeker et al., 2018).

Low-temperature thermochronology recorded a Middle Triassic - Early Jurassic cooling event affecting the Song-Kul basement (De Grave et al., 2011) interpreted as relief building. This exhumation episode has been followed by a Middle Jurassic - Paleogene period of slow cooling (Fig. 5) (De Grave et al., 2011) that should correspond to a general flattening of the topography of the area. In the Ming-Kush Basin, the hiatus in sedimentation between the Jurassic and the Paleogene is coeval with this period of slow cooling identified by lowtemperature thermochronology data. This also suggests that the region was characterized by low relief associated to slow erosion during its Jurassic to Paleogene evolution. The Oligo- 
Miocene conglomerates unconformably lying on the previous deposits (Lasovskiy and Mozolev, 1961; De Pelsmaeker et al., 2018) could then indicate a renewing of the topography within this area, associated to the onset of tectonic deformation in the range.

\section{1. 2. The Naryn region}

The Naryn region includes both MTS and South Tian Shan (STS) terranes and is located to the south of the Nikolaev Line, corresponding to a combination of late Paleozoic thrusts and strike-slip faults (Fig. 4). To the south of this fault zone, three intra-mountain basins stand from the north to the south: the Naryn, Atbashi and Aksai basins (Figs. 1 and 4). The basement of the Naryn area is similar to that of the southern Song-Kul region. In the Atbashi Range, this basement consists of Middle to Late Ordovician volcanic rocks intruded by Silurian to Carboniferous magmatism (Glorie et al., 2011; Alexeiev et al., 2016). Permian collisional and post-collisional magmatism also occurred within this area (Konopelko et al., 2007; De Grave et al., 2011; 2013). In the Kokshaal Range, the STS terrane rather consists of Silurian to early Permian marine sediments and igneous rocks (Konopelko et al., 2007; Glorie et al., 2011; Jourdon et al., 2017).

Planation surfaces are ubiquitous within the Naryn region and the Kokshaal Range to the south (Fig. 4) (Burbank et al., 1999). They cross-cut Paleozoic rocks and are generally tilted by the Cenozoic deformation (Fig. 6) as well as locally strongly reworked by river incision. Along the southern margin of the Naryn Basin, a tilted planation surface is also mantled by Oligocene-Miocene sediments (Figs. 5, 6) (Burbank et al., 1999) constraining the age of its formation between the Carboniferous and the Oligocene (Karpovitch et al., 1964). In the Kokshaal Range, the erosional surface cross-cuts early Permian granitoids (Glorie et al., 2011) and is locally mantled by Neogene sediments (Karpovitch et al., 1964). In the Naryn Basin, patchy Jurassic coal-bearing continental sediments unconformably overly folded 
Paleozoic rocks (Fig. 5) (VNIGNI and Beicip Franlab, 1992). A Middle Jurassic to Eocene hiatus in sedimentation corresponding to a weathered layer was also identified within the basin (VNIGNI and Beicip Franlab, 1992; Burbank et al., 1999). Above, up to 4-6 km thick Oligocene to Quaternary strata consist of alluvial to lacustrine deposits unconformably overlying the Jurassic to Paleozoic rocks (VNIGNI and Beicip Franlab, 1992; Burbank et al., 1999; Macaulay et al., 2014).

In the Atbashi Range, low temperature thermochronology data recorded a strong Early to Middle Jurassic cooling event followed by a protracted Late Jurassic-Paleogene period of slow cooling (Fig. 5) (Glorie et al., 2011). The hiatus identified in the Naryn Basin is coeval with this protracted period of slow cooling indicating that this region was characterized by low relief from the Middle Jurassic to the Eocene. To the south of the Aksai Basin, in the Kokshaal Range (Fig. 4), low temperature thermochronology data identified an Early Cretaceous enhanced cooling period followed by a Late Cretaceous to present-day phase of continuous slow cooling (Glorie et al., 2011). Finally, localized Paleogene and Neogene cooling periods have also been identified from low temperature thermochronology data in the Atbashi Range (Glorie et al., 2011) indicating tectonic reactivation and relief-build up.

\section{1. 3. The Issyk-Kul region}

The Issyk-Kul Basin is an intra-mountain depression bordered by the Zhetizhol Range to the north-west, the Trans-Ili and Kungey ranges to the north, and by the Terskey Range to the south (Fig. 4). In this region, the basement belongs to the NTS terrane and consists predominantly of Precambrian continental fragments intruded by early Paleozoic granitoids and by early Permian post-collisional plutons (Konopelko et al., 2008; Glorie et al., 2011; Alexeiev et al., 2016). 
Numerous planation surfaces are exposed to the north of the Issyk-Kul Basin, within the Zhetizhol, Trans-Ili and Kungey ranges (Fig. 4). They cross-cut Paleozoic rocks and are generally horizontal or slightly tilted by the Cenozoic deformation (Fig. 4) (Jenchuraeva et al., 2001; Tursungaziev and Petrov, 2008). These surfaces are locally mantled by Neogene to Quaternary sediments (Jenchuraeva et al., 2001; Tursungaziev and Petrov, 2008) constraining their evolution to pre-Neogene time. In the Issyk-Kul Basin, patchy Jurassic sediments unconformably overly the strongly deformed Paleozoic basement (VNIGNI and Beicip Franlab, 1992; Macaulay et al., 2014; De Pelsmaeker et al., 2018). They consist of shale and of fine to coarse-grained sandstones containing caliche paleosols and numerous oxidized layers (De Pelsmaeker et al., 2018). These meters- to hundred meters-thick deposits are unconformably overlain by thin (up to $100 \mathrm{~m}$ ) Paleocene to Oligocene sediments composed of m-thick calcrete layers (Cobbold et al., 1994; De Pelsmaeker et al., 2018). Those are followed by up to $2 \mathrm{~km}$-thick Oligocene-Miocene coarse-grained deposits (Macaulay et al., 2014). Finally, an erosional unconformity is visible at the base of Pliocene sediments corresponding to up to $3 \mathrm{~km}$-thick of mainly alluvial and lacustrine deposits (VNIGNI and Beicip Franlab, 1992; Macaulay et al., 2014).

In the Zhetizhol and Kungey ranges, low-temperature thermochronology data identified a Jurassic episode of rapid cooling followed by a Late Jurassic/Cretaceous - Oligocene period of slow denudation (Fig. 5) (De Grave et al., 2013; Glorie et al., 2016). This suggests that strong relief building occurred during the Lower - Middle Jurassic but that this relief was thereafter flattened by Early Cretaceous times. In the Trans-Ili Range, low-temperature thermochronology data only identified a Late Cretaceous-Paleogene cooling phase (Fig. 5) (De Grave et al., 2013). Finally, late Paleogene to Neogene cooling within major fault zones around the Issyk-Kul Basin have been recorded within all these ranges indicating that localized relief building occurred during the Cenozoic, in relation with the tectonic 
reactivation of the Tian Shan Range (Fig. 5) (De Grave et al., 2013; Glorie et al., 2016). In the Issyk-Kul Basin, the occurrence of both Jurassic and Paleocene-Oligocene paleosols with a long lasting hiatus in sedimentation inbetween also suggests that this area was characterized by low reliefs during its Jurassic to Paleogene evolution. Then, during the Oligo-Miocene, a renewed subsidence was recorded within the basin and sedimentation was characterized by coarse-grained deposits indicating that renewed relief build-up occurred in the area. This is in agreement with the low temperature thermochronology data discussed above (De Grave et al., 2013; Macaulay et al., 2014; Glorie and De Grave, 2016). The erosional unconformity at the base of the Pliocene deposits also supports that renewed relief build-up in the region.

\section{2. South Kazakhstan and Chinese Tian Shan regions}

\section{2. 1. The Yili-Balkhash region}

The Yili-Balkhash basement belongs to the NTS terrane and consists of Precambrian microcontinental blocks, Cambrian to early Silurian island arcs and Paleozoic magmatic arcs and accretionary complexes (Windley et al., 2007; Willhem et al., 2012; De Pelsmaeker et al., 2015). In this region, numerous large-scale, well-preserved low-relief surfaces are visible in the Aktau Range (Figs. 4, 7). These surfaces cross-cut Paleozoic rocks and some are locally mantled by Neogene sediments (Bekzhanov 1997). To the west, in the Yili-Balkhash Basin, Triassic-Jurassic sediments unconformably overly the Paleozoic basement (Fig. 4) (VNIGNI and Beicip Franlab, 1992). These deposits are themselves unconformably overlaid by patchy Upper Cretaceous sediments consisting of an alternation of gravels, sandstones and clays (VNIGNI and Beicip Franlab, 1992). Paleogene deposits then rest unconformably on the Upper Cretaceous sediments (Lucas et al., 2000) and consist mainly of fluvio-lacustrine deposits reflecting rather low-energy depositional environments (Lucas et al., 1997; Kober et al., 2013). 
In the Aktau Range, low temperature thermochronology data identified a late Mesozoic rapid cooling followed by a Late Cretaceous - Paleogene period of slow cooling (De Pelsmaeker et al., 2015). A late Cenozoic reactivation of the range has then been identified from lowtemperature thermochronology data (De Pelsmaeker et al., 2015) and is also marked within the Yili-Balkhash Basin by coarser-grained sedimentation since the Middle Miocene (Kober et al., 2013; Lucas et al., 1997, 2000).

\section{2. 2. The Yili region}

In the Yili region, the Yili and Zahosu basins are intra-mountain depressions bordered by the Borohoro Range to the north and by the Narat Range to the south (Fig. 4). The Yili basement belongs to the Kazakhstan-Yili block and consists of Proterozoic metasedimentary rocks and gneisses, Ordovician-Silurian volcanic arcs and Devonian-Carboniferous volcanics and marine sediments (Jun et al., 1998; Alexeiev et al., 2015).

Numerous erosional surfaces are visible within all the mountain ranges surrounding the Yili and Zahosu basins (Fig. 4). To the north, in the Borohoro Range, these surfaces are either subhorizontal or tilted by the Cenozoic deformation (Fig. 8A). They cross-cut Paleozoic rocks and are locally mantled by Paleogene to Neogene sediments (AGMCA, 2008; Jolivet et al., 2018). Further south, in the Awuela Range (Fig. 8B), an erosional surface is also visible but has the particularity to be locally overlaid by Upper Cretaceous sediments (Fig. 8C; XBGMR, 1973). This indicates that this surface was established prior to the Late Cretaceous in this area. Erosional surfaces are also visible within the Yishenjilike Range separating the Yili and Zahosu basins (Fig. 4). These surfaces cross-cut Permian rocks and are locally mantled by Middle Jurassic sediments (AGMCA, 2008) limiting their establishment to pre-Middle Jurassic times. 
The sedimentary filling of the Yili and Zahosu basins is characterized by Permian to Quaternary deposits. In the Zahosu Basin, the Permian series consist of marine sediments followed by the emplacement of Upper Permian volcanics and volcanoclastics deposits (Li et al., 2015). These series are unconformably overlaid by Early - Middle Jurassic sediments corresponding to alluvial to lacustrine deposits containing extensive coal beds (Li et al., 2014; Li et al., 2015). The stratigraphic evolution of both the Yili and Zahosu basins is then characterized by a Late Jurassic to Early Cretaceous hiatus in sedimentation (Fig. 5) (VNIGNI and Beicip Franlab, 1992; Li et al., 2015) marked by a 40 m-thick weathered layer overlain by Upper Cretaceous sediments (VNIGNI and Beicip Franlab, 1992). The first hiatus between the Permian and Jurassic in the sedimentation of the Zahosu Basin indicates that no sediment was deposited or that the area was under erosion during its Triassic evolution. Then, the Late Jurassic to Early Cretaceous hiatus in the sedimentation of the both basins also suggests that no sediment was deposited in the Yili area or that this area was under erosion (VNIGNI and Beicip Franlab, 1992).

\section{2. 3. The Bayanbulak and South Tian Shan regions}

The Bayanbulak Basin is an intra-mountain depression located between the Narat Range to the north, the South Tian Shan Range to the south, and the Erbin Shan Range to the east (Fig. 4). Its basement belongs to the STS terrane and consists mainly of Silurian-Devonian volcanic rocks and volcano-sedimentary deposits (Alexeiev et al., 2015), Devonian-Carboniferous ophiolitic mélanges, magmatic, metamorphic and sedimentary rocks (Charvet et al., 2011; Alexeiev et al., 2015).

The Bayanbulak and South Tian Shan regions display numerous large-scale erosional surfaces (Figs. 4, 9). These surfaces cross-cut Paleozoic rocks and presents various morphologies. Some are horizontal and well-preserved (Fig. 9A) while others are tilted by the Cenozoic 
deformation and extensively degraded by rivers (Fig. 9B). In the Bayanbulak region, they are locally covered by Oligocene sediments (Fig.5) (AGMCA, 2008).

In the Narat Range, low temperature thermochronology data indicate continuous PermianEarly Jurassic sustained cooling followed by a Middle Jurassic to Late Cretaceous period of slow cooling (Fig. 5) (Dumitru et al., 2001; Jolivet et al., 2010). In the Erbin Shan Range, similar data identified Permian - Middle Jurassic sustained cooling followed by Late Jurassic - Paleogene slow cooling (Dumitru et al., 2001; Jolivet et al., 2010). The lack of Cretaceous sediments in the Bayanbulak Basin, together with the slow cooling identified by the lowtemperature thermochronology data, indicate that this region was characterized by low relief during its Middle Jurassic to Paleogene evolution. However, localized Late CretaceousPaleogene cooling along the Narat fault has been identified indicating that discrete late Mesozoic - early Cenozoic relief building occurred in this area along the major tectonic structures that are still currently active (Jolivet et al., 2010).

\section{2. 4. The Bogda Shan region}

The Bogda Shan basement belongs to the NTS terrane and consists of Middle - Late Carboniferous volcanic, pyroclastic, granitic and carbonate rocks (Allen et al., 1993). In the topography of this range, large-scale erosional surfaces cross-cutting Paleozoic rocks are exposed, but they are partly reworked by glaciers and river incisions (Figs. 4, 10). In both the Junggar and Turfan basins that form the north and south piedmonts of the Bogda Shan Range, Middle - Upper Jurassic fine-grained alluvial to lacustrine deposits are unconformably overlaid by Upper Jurassic - Lower Cretaceous coarse-grained alluvial sediments (Hendrix et al., 1992; Shao et al., 1999; Shao et al., 2003; Bian et al., 2010; Yang et al., 2015). Lower Cretaceous fine-grained alluvial to lacustrine sediments were subsequently deposited within both basins (Hendrix et al., 1992; Shao et al., 1999), before being unconformably overlaid by 
Upper Cretaceous alluvial fan deposits (Hendrix et al., 1992; Shao et al., 1999). Along the southern margin of the Junggar Basin, the Paleogene sediments then contain thick calcrete layers (Heilbronn et al., 2015).

In the northern part of the Bogda Shan Range, low temperature thermochronology data identified a strong cooling event in the latest Jurassic time followed by a Late Cretaceous Paleogene period of slow cooling (Fig. 5) (Tang et al., 2015). In the Junggar and Turfan basins, the Late Jurassic unconformity and the overlying Upper Jurassic - Lower Cretaceous coarse-grained sediments also indicate that some relief building occurred within the Bogda Shan region during the Late Jurassic - Early Cretaceous transition. Then, the Cretaceous unconformity and the overlying Upper Cretaceous alluvial fan deposits suggest that this region underwent a second phase of relief building during its Late Cretaceous evolution. Following this second phase of relief building, the Paleogene calcrete layers along the southern margin of the Junggar Basin suggest very low subsidence rates and the absence of strong contemporaneous vertical tectonic movements (Heilbronn et al., 2015; Jolivet et al., 2018). Finally, Oligocene reactivation of the Bogda Shan has been identified by low temperature thermochronology data (Fig. 5) (Tang et al., 2015).

\section{Buried planation surfaces of the Eastern Tarim Basin}

From Late Precambrian to Quaternary, the Tarim Basin underwent multiple phases of tectonic deformation. Evidences of these deformations are preserved within its stratigraphic record as erosional surfaces. We analyzed seismic profiles from the eastern Tarim Basin to investigate the genesis of these surfaces and duration of these planation periods (Fig. 11).

In the Eastern Tarim, the oldest surface (S4) is thus an intra-Devonian angular unconformity that truncates the underlying units to the south and which is itself truncated by Late Devonian - Early Carboniferous unconformity (S3) in the center of the basin (Fig. 10A. 1). This 
geometry reveals an uplift of the southern Tarim during the Devonian, the northern part of the basin still being subsident. In contrast, the Late Devonian - Early Carboniferous erosion surface (S3) reflects an uplift of the central and northern part of the basin. In the same time, the formerly uplifting southern Tarim became slightly subsident.

Within the Mesozoic series, a Late Triassic - Early Jurassic surface (S2) represents a major angular unconformity between folded and truncated Paleozoic to Triassic units and the flatlying, Jurassic reflectors (Figs. 11A.1, B.1, B.2), which onlap onto these units in the western part of the basin

A Late Jurassic - Early Cretaceous surface (S1) corresponds to a slight angular unconformity to the south passing to a conformable surface to the north (Figs. 11A.1; B.2). To the south, this unconformity truncates the previous erosive surfaces S4, S3 and S2 (Figs. 11A.1, B.2). This indicates that during the Late Jurassic - Early Cretaceous transition, the south-eastern part of the Tarim Basin remained above the relative base level. In this part of the basin, it can also be noticed that this surface displays two distinct morphological compartments separated by a south-dipping Cretaceous reverse fault (Figs. 11A; A.2). In the footwall of the fault, the surface appears almost flat whereas in its hanging wall it shows $\approx 170$ to $350 \mathrm{~m}(100-250$ msTWT) deep paleovalleys, filled by Cretaceous sediments. The occurrence of this thrust and the induced incision of the erosion surface (S1r) indicate a Cretaceous compressive tectonic activity in the north Tibet - south Tarim region. In contrast, to the north, the thickness of the Jurassic deposits comprised between this surface $\mathrm{S} 1$ and the previous one $\mathrm{S} 2$ increases northward (Fig. 11). This indicates that during the Jurassic, the northern part of the basin was slightly subsiding with reflectors onlapping the surface S2. This is consistent with the moderate Late Jurassic - Early Cretaceous vertical movements described in the Tian Shan Range and the occurrence of an eroding relief in that area (e.g. Glorie et al., 2011; De Grave et al., 2013; Tang et al., 2015). 
Finally a Late Cretaceous - Paleocene surface (S0) corresponds to a localized slight angular unconformity marked by toplap terminations of the Mesozoic sediments and by onlap of the Cenozoic sediments above (Fig. 11B.1). This erosive surface indicates an uplift of the northern Tarim Basin during the Late Cretaceous-Paleogene transition before being subsequently covered by the Cenozoic sediment infill. However, the presence of several meters-thick Late Cretaceous-Paleogene calcareous paleosols in the Yaha region (northern Tarim Basin) indicates very low subsidence rates and therefore that only limited uplift occurred at that time (Jolivet et al., 2018).

In the western Tarim Basin, several Paleozoic unconformities have been described (e.g., Lin et al., 2012; He et al., 2016; Liu et al., 2016). However, in this region, except for the Jurassic sediments exposed along the West Kunlun - Pamir Range (Lee 1985a, b; Sobel et al., 1999; Yang et al., 2017), Upper Cretaceous to Cenozoic strata unconformably overly Paleozoic rocks (e.g., Wei et al., 2013) indicating that this area was under erosion for most of the Mesozoic period.

\section{Ages and long-term evolution of the planation surfaces}

The flat erosional surfaces exposed in the Tian Shan region are generally inferred to have developed during a Late Cretaceous - Early Paleogene period of tectonic quiescence (Cunningham et al., 2003; De Grave et al., 2007; De Pelsmaeker et al., 2015). However, some studies proposed that they were already established by Jurassic time (Jolivet et al., 2010; Glorie and De Grave, 2016; Gillepsie et al., 2017). By compiling available low-temperature thermochronology and stratigraphic data we demonstrate that the planation surfaces visible in the Tian Shan Range and within the Tarim Basin have a more complex genesis than previously thought (Fig. 12). 
In the Tarim Basin, the two late Paleozoic erosional surfaces (S4 and S3) developed along the northern and southern margins where the basin underwent strong uplift and erosion (Lin et al., 2012; Liu et al., 2016). However, these erosional surfaces cannot be the one preserved under the form of horizontal erosional surfaces in the Tian Shan Range. Indeed, these latter surfaces cross-cut Permian granitoids which indicates that they were established later. Moreover, throughout the Tian Shan region, continuous Permian - Triassic cooling has been identified by low-temperature thermochronology data followed by a period of Late Triassic - Early Jurassic period of enhanced cooling (Dumitru et al., 2001; Jolivet et al., 2010; De Grave et al., 2011, 2013). This Late Triassic - Early Jurassic period of tectonic activity and erosion is supported by the presence of an angular unconformity at the base of the Jurassic series within the Naryn and Issyk-Kul basins (Fig. 5) and in the eastern Tarim Basin where it results in a major erosional event partially rejuvenating the Paleozoic surfaces (Fig. 11. A.1). In addition, in the Zahosu depression and Bayanbulak Basin, a Triassic hiatus is observed in the sedimentation (Li et al., 2015) contemporaneous to a continuous slow cooling identified within the Narat Range (Dumitru et al., 2001; Jolivet et al., 2010). This suggests that the region also underwent erosion during this period leading to the establishment of a planation surface. In both basins, coal-bearing Lower - Middle Jurassic sediments seal this erosional surface (Li et al., 2015). Finally, this Permian - Early Jurassic erosional surface is visible within the Yishenjilike Range (Yili region, see Fig. 4 for location; Fig. 12) where it is mantled by Middle Jurassic sediments (AGMCA, 2008).

Following the Late Triassic - Early Jurassic tectonic activity, the Jurassic marks the onset of a progressive lowering of the Tian Shan relief indicated by the genesis of a regional scale erosional surface. This flattening of the topography is also well characterized by sedimentological studies which identified a transition from Upper Triassic - Lower Jurassic coarse-grained sediments associated with braided fluvial environments to Middle Jurassic 
organic-rich meandering-fluvial and lacustrine deposits in both the Junggar and Tarim basins (Hendrix et al., 1992; Eberth et al., 2001; Yang et al., 2015; De Pelsmaeker et al., 2018; Morin et al., 2018). The widespread occurrence of Middle Jurassic coal layers associated to fine - grained sediments throughout the Tian Shan region confirms that most of the relief was already flattened by Middle Jurassic time under rather humid conditions.

During the Middle Jurassic - Cretaceous period, most of the Tian Shan area then appears to be dominated by relatively low exhumation rates while most of the intra-mountain basins were dominated by sedimentary hiatuses (see Fig. 5 and references therein). However, localized Late Jurassic - Early Cretaceous low-temperature thermochronology ages are reported from the western Tian Shan (De Grave et al., 2007; Glorie et al., 2011; De Grave et al., 2013) and from the Bogda Shan regions (Fig. 5) (Tang et al., 2015). They indicate that tectonic activity and exhumation still occurred throughout the Late Jurassic- Early Cretaceous transition. These data are in agreement with provenance analyses which demonstrate that recycling of Mesozoic sediments took place along the Northern Tian Shan foothills during the Late Jurassic - Early Cretaceous (Yang et al., 2013), and by angular unconformities locally associated with incised paleo-valleys in the Altai piedmont (Eberth et al., 2001).

Finally, this exhumation is inferred in the Tarim Basin as well (surface S1), where renewed subsidence activated to the north-east, along the southern Tian Shan piedmont (Figs. 11A.1; B.2). This indicate that localized reactivation of the relief occurred in the Tian Shan area with erosion that could have locally reworked the previously established flat surfaces.

This period was marked by a change in climate, recorded all over the Tian Shan area by the disappearance of the humid conditions marked by coal layers and the extensive formation of calcareous paleosols, indicative of semi-arid conditions (Hendrix et al., 1992; Eberth et al., 2001; Vincent et al., 2001; De Pelsmaeker et al., 2018; Jolivet et al., 2018b; Morin et al., 
2018). In the southern Junggar Basin, this aridity is marked by the development of large aeolian dunes (Jolivet et al., 2017). This change to semi-arid conditions could have had a major impact on the preservation of the flat surfaces by reducing the efficiency of erosion processes, especially that of river incision and chemical alteration. Eventually, in the Tarim Basin, incision of the Late Jurassic-Early Cretaceous erosional surface (S1r) driven by activity on discrete tectonic structures, has led to the establishment of small hills (150-400 m above the surface) and to the development of local drainage systems (Fig. 11A.2). Late JurassicEarly Cretaceous incised valleys filled with alluvial fans were also described in the Junggar Basin (Eberth et al., 2001) implying that some relief already existed prior to the Cenozoic orogeny in both regions.

By Late Cretaceous, renewed sedimentation occurred within the intra-mountain basins of the Tian Shan, locally burying the previously established planation surfaces (e.g. Yili region; Fig. 8C). In both the Tarim and Junggar basins, Upper Cretaceous coarse-grained alluvial sediments unconformably overlay Lower Cretaceous fine-grained alluvial to lacustrine deposits (Hendrix et al., 1992). Similarly, to the north of the Tian Shan region, renewed Late Cretaceous subsidence occurred in the Chu-Sarysu Basin (VNIGNI and Beicip Franlab, 1992). We attribute this renewed subsidence associated with coarse-grained deposits to renewed deformation in the Tian Shan Range. This exhumation event has only been identified by low-temperature thermochronology in the Aktau Range in Kazakhstan (De Pelsmaeker et al., 2015) and has probably established the planation surfaces visible within this area (Fig. 12).

Late Cretaceous - Early Paleogene exhumation has then been identified by low temperature thermochronology along major faults within the Tian Shan region (Fig. 5 and references therein). It is also expressed within the Tarim stratigraphic record by the emplacement of angular unconformities (Fig. 11B.1). This implies that localized relief building occurred 
within the Tian Shan Range, possibly locally reworking pre-Cenozoic planation surfaces (Jolivet et al., 2018). However, Paleogene sediments present numerous paleosols layers (Lucas et al., 1997; Heilbronn et al., 2015; De Pelsmaeker et al., 2018; Jolivet et al., 2018b) indicating that the range was still mostly dominated by flat reliefs. We therefore propose that most of the planation surfaces were still active during this period (Fig. 12).

Finally, a late Paleogene-Neogene exhumation localized along major tectonic structures has been identified throughout the Tian Shan by low temperature thermochronology (Fig. 5 and references therein). By Oligocene-Miocene, renewed subsidence occurred within the intramountain basins, associated to the deposition of coarse-grained alluvial sediments (e.g., VNIGNI and Beicip Franlab, 1992; Kober et al., 2013; Lucas et al., 1997, 2000; Macaulay et al., 2014; De Pelsmaeker et al., 2018). These Oligo-Miocene deposits locally seal the planation surfaces in the Tian Shan region while the renewed late Cenozoic tectonic activity led to the exhumation and tilting of others (Fig. 12) (e.g., Burbank et al., 1999; Sobel et al., 2006a).

\section{Implication for the balance between tectonic uplift and erosion}

The long-term preservation of Paleozoic to Mesozoic topographic relics within the active Tian Shan Range implies very limited mean denudation rates leading to a pronounced state of nonequilibrium between tectonic uplift and erosion during the Cenozoic evolution of the range. Tectonic uplift of the range initiated during the late Oligocene and largely increased around $10 \mathrm{Ma}$ (Sobel et al., 2006b; Charreau et al., 2006), leading to localized exhumation along major faults (Dumitru et al., 2001). Despite significant tectonic activity $(10 \pm 3 \mathrm{~mm} / \mathrm{yr}$ shortening in the northern Tian Shan region), its average denudation rate is comparable to that of flat Middle Europe (a few $\approx 100 \mathrm{~m} / \mathrm{Ma}$ ) (Guerit et al., 2016). These limited denudation rates and the probable associated disequilibrium between tectonic uplift and erosion could 
have been promoted by the arid to semi-arid climate prevailing since the Late Jurassic (Hendrix et al., 1992). Such disequilibrium driven by the semi-arid climate has already been suggested for the Cenozoic period (Guerit et al., 2016; Charreau et al., 2017).

However, despite this prolonged state of disequilibrium it appears that most of the preserved planation surfaces visible within the Tian Shan region are now generally dissected by river incision and should ultimately be destroyed during the Cenozoic orogeny. This observation, together with the long-term preservation of Paleozoic to Mesozoic topographic relics within the Tian Shan Range, implies that the region did not undergo strong tectonic reactivation for most of its Mesozoic evolution. During this period, the Tian Shan topography might have been in a relative state of equilibrium, dominated by plains and small hills rising along discrete tectonic structures.

\section{Conclusion}

By synthesizing low-temperature thermochronology and stratigraphic data on the Tian Shan region as well as describing the planation surfaces preserved within the eastern Tarim Basin we demonstrate that different generation of surfaces are preserved within this region. Following several late Paleozoic planation periods visible within the Tarim Basin, a largescale planation surface formed during the Mesozoic evolution of the range and was locally reworked during short-lived periods of tectonic activity. The widespread preservation of large fragments of these pre-orogenic surfaces within the Tian Shan Range implies that this region did not undergo strong relief building during most of its Mesozoic evolution but was dominated by flat-reliefs and small hills localized along discrete tectonic structures. Finally, the preservation of these surfaces within the present-day active Tian Shan Range also implies a long-term, strong non-equilibrium state of the topography during its Cenozoic evolution. 
This was probably promoted by the arid to semi-arid climate prevailing in the area during this whole period.

\section{Aknowledgments}

The study presented here was conducted with research grants from the DARIUS (M.J), the CNRS-INSU SYSTER (L.B.) program, and the China Geological Survey grant DD20160022 (H.L.). J.M and A.L. benefitted from a PhD grant from the French Ministry of Research and Higher Education (MESR). The seismic and well data used for this study are a courtesy of the Sinopec Group of the China Petrochemical Corporation. The work of L.B. and A.L. for this article is the IPGP contribution \#3847.

\section{References}

Atlas of Geological Maps of Central Asia and Adjacent Areas (AGMCA). Geological Map 1: 2500 000, Beijing: Geological Publishing House, 2008.

Alexeiev, D. V., Biske, Yu. S., Wang, Bo., Djenchuraeva, A.V., Getman, O. F., Aristov, V. A., Kröner, A., Liu, H., Zhong, L., 2015, Tectono-Stratigraphic Framework and Paleozoic Evolution of the Chinese South Tianshan: Geotectonics, 49(2), 93-122.

Alexeiev, D. V., Kröner, A., Hegner, E., Rojas-Agramonte, Y., Biske, Y. S., Wong, J., Ivleva, E. A., Mühlberg, M., Liu, D., 2016. Middle to Late Ordovician arc system in the Kyrgyz Middle Tianshan: From arc-continent collision to subsequent evolution of a Palaeozoic continental margin. Gondwana Research, 39, 261-291.

Allen, M. B., Windley, B. F., Zhang, C., Guo, J., 1993. Evolution of the Turfan basin, Chinese central Asia. Tectonics, 12(4), 889-896. 
Allen, M. B., Vincent, S. J., and Wheeler, P. J., 1999. Late Cenozoic tectonics of the Kepingtage thrust zone: interactions of the Tien Shan and Tarim Basin, northwest China. Tectonics, 18(4), 639-654.

Avouac, J. P., and Peltzer, G., 1993a. Active tectonics in southern Xinjiang, China: Analysis of terrace riser and normal fault scarp degradation along the Hotan- Qira fault system. Journal of geophysical research: solid earth, 98(B12), 21773-21807.

Bekzhanov, G. R. (Chief editor) 1997. Geological Map of Kazakhstan. Scale 1:1.000.000, CSFDFJ (VSEGEI). All-Russian Research Institute of Geology, St Petersburg.

Bessin, P., Guillocheau, F., Robin, C., Schroëtter, J. M., Bauer, H., 2015. Planation surfaces of the Armorican Massif (western France): Denudation chronology of a Mesozoic land surface twice exhumed in response to relative crustal movements between Iberia and Eurasia. Geomorphology, 233, 75-91.

Bian, W., Hornung, J., Liu, Z., Wang, P., Hinderer, M., 2010. Sedimentary and palaeoenvironmental evolution of the Junggar Basin, Xinjiang, Northwest China. Palaeobiology Palaeoenvironment, 90, 175-186.

Burbank, D. W., McLean, J. K., Bullen, M., Abdrakhmatov, K. Y., Miller, M. M., 1999. Partitioning of intermontane basins by thrust-related folding, Tien Shan, Kyrgyzstan. Basin Research, 11, (1), 75-92.

Burchfiel, B. C., Brown, E. T., Qidong, D., Xianyue, F., Jun, L., Molnar, P., Jianbang, S., Zhangming, W., Huichuan, Y., 1999. Crustal shortening on the margins of the Tien Shan, Xinjiang, China. International Geology Review, 41(8), 665-700. 
Calvet, M., Gunnell, Y., Farines, B., 2015. Flat-topped mountain ranges: Their global distribution and value for understanding the evolution of mountain topography. Geomorphology, 241, 255-291.

Carroll, A. R., Graham, S. A., Chang, E. Z., and McKnight, C., 2001. Sinian through Permian tectonostratigraphic evolution of the northwestern Tarim basin, China. Memoirs-Geological Society of America, 47-70.

Charreau, J., Saint-Carlier, D., Dominguez, S., Lavé, J., Blard, P. H., Avouac, J. P., Jolivet, M., Chen, Y., Wang, S-L., Brow, N, D., Malatesta, L. C., 2017. Denudation outpaced by crustal thickening in the eastern Tianshan. Earth and Planetary Science Letters, 479, 179-191.

Charvet, J., Shu, L., Laurent-Charvet, S., Wang, B., Faure, M., Cluzel, D., Chen, Y., and De Jong, K., 2011, Palaeozoic tectonic evolution of the Tianshan belt, NW China: Science China Earth Sciences, 54(2), 166-184.

Chen, Z. Q., and Shi, G. R., 2003. Late Paleozoic depositional history of the Tarim basin, northwest China: an integration of biostratigraphic and lithostratigraphic constraints. AAPG bulletin, 87(8), 1323-1354.

Clark, M. K., Royden, L. H., Whipple, K. X., Burchfiel, B. C., Zhang, X., Tang, W., 2006, Use of a regional, relict landscape to measure vertical deformation of the eastern Tibetan Plateau: Journal of Geophysical Research, 111, F03002.

Coltorti, M., Dramis, F., Ollier, C. D., 2007. Planation surfaces in northern Ethiopia. Geomorphology, 89(3-4), 287-296.

Cunningham, W.D., Dijkstra, A.H., Howard, J., Quarles, A., and Badarch, G., 2003, Active intraplate strike-slip faulting and transpression uplift in the Mongolian Altai, in Storti, F., et 
al., eds., Interplate strike-slip deformation belts: Geological Society [London] Special Publication 210, 65-87.

De Grave, J., and Van den Haute P., 2002, Denudation and cooling of the Lake Teletskoye Region in the Altai Mountains (South Siberia) as revealed by apatite fission-track thermochronology: Tectonophysics, 349, 145-159.

De Grave, J., Buslov, M. M., Van den haute, P., 2007, Distant effects of India-Eurasia convergence and Mesozoic intracontinental deformation in Central Asia: Constraints from apatite fission-track thermochronology: Journal of Asian Earth Sciences, 29, 188-204.

De Grave, J., Glorie, S., Buslov, M. M., Izmer, A., Fournier-Carrie, A., Batalev, V. Y., Vanhaecke, F., Elburg, M., Van den haute, P., 2011. The thermo-tectonic history of the SongKul plateau, Kyrgyz Tien Shan: constraints by apatite and titanite thermochronometry and zircon U/Pb dating. Gondwana Research, 20(4), 745-763.

De Grave, J., Glorie, S., Buslov, M. M., Stockli, D. F., McWilliams, M. O., Batalev, V. Y., 2013. Thermo-tectonic history of the Issyk-Kul basement (Kyrgyz northern Tien Shan, Central asia). Gondwana Research, 23, (3), 998-1020.

De Pelsmaeker, E., Glorie, S., Buslov, M., M., Zhimulev, F. I., Poujol, M., Korobkin, V. V., Vanhaecke, F., Vetrov, E. V., De Grave, J., 2015. Late-Paleozoic emplacement and MesoCenozoic reactivation of the southern Kazakhstan granitoid basement. Tectonophysics, 662, 416-433.

De Pelsmaeker, E., Jolivet, M., Laborde, A., Poujol, M., Robin, C., Zhimulev, F. I., Nachtergaele, S., Glorie, S., De Clercq, S., Batalev, V. Y., De Grave, J., 2018. Source-to-sink dynamics in the Kyrgyz Tien Shan from the Jurassic to the Paleogene: Insights from sedimentological and detrital zircon U-Pb analyses. Gondwana Research, 54, 180-204. 
Desheng, L., Digang, L., Chengzao, J., Gang, W., Qizhi, W., Dengfa, H., 1996. Hydrocarbon accumulations in the Tarim basin, China. AAPG bulletin, 80(10), 1587-1603.

Dumitru, T. A., Zhou, D., Chang, E. Z., Graham, S. A., Hendrix, M. S., Sobel, E. R., Carroll, A. R., 2001, Uplift, exhumation, and deformation in the Chinese Tian Shan: MemoirsGeological Society of America, 114, 71-100.

Eberth, D. A., Brinkman, D. B., Chen, P. J., Yuan, F. T., Wu, S. Z., Li, G., Cheng, X. S., 2001. Sequence stratigraphy, paleoclimate patterns, and vertebrate fossil preservation in Jurassic Cretaceous strata of the Junggar Basin, Xinjiang Autonomous Region, People's Republic of China. Canadian Journal of Earth Sciences, 38, (12), 1627-1644.

England, P., Molnar, P., 1990. Surface uplift, uplift of rocks, and exhumation of rocks: Geology, 18, 1173-1177.

Gao, J., Li, M., Xiao, X., Tang, Y., He, G., 1998. Paleozoic tectonic evolution of the Tianshan orogen, northwestern China. Tectonophysics, 287, 213-231.

Gao, J., Long, L., Klemd, R., Qian, Q., Liu, D., Xiong, X., Su, W., Liu, W., Wang, Y., Yang, F., 2009. Tectonic evolution of the South Tianshan orogen and adjacent regions, NW China: geochemical and age constraints of granitoid rocks. International Journal of Earth Sciences, 98(6), 1221.

Gillespie, J., Glorie, S., Jepson, G., Zhang, Z. Y., Xiao, W. J., Danišík, M., Collins, A. S., 2017. Differential Exhumation and Crustal Tilting in the Easternmost Tianshan (Xinjiang, China), Revealed by Low- Temperature Thermochronology. Tectonics, 36, (10), 2142-2158.

Glorie, S., De Grave, J., Buslov, M. M., Zhimulev, F. I., Stockli, D. F., Batalev, V. Y., Izmer, A., Van den Haute, P., Vanhaecke, F., Elburg, M. A., 2011. Tectonic history of the Kyrgyz 
South Tien Shan (Atbashi- Inylchek) suture zone: The role of inherited structures during deformation- propagation. Tectonics, 30(6).

Glorie, S., De Grave, J., 2016. Exhuming the Meso-Cenozoic Kyrgyz Tianshan and Siberian Altai-Sayan: a review based on low-temperature thermochronology. Geoscience Frontiers, 7, (2), 155-170.

Guerit, L., Barrier, L., Jolivet, M., Fu, B., Métivier, F., 2016, Denudation intensity and control in the Chinese Tian Shan: new constraints from mass balance on catchment-alluvial fan systems: Earth Surface Processes and Landforms, DOI: 10.1002/esp.3890.

Greene, T. J., Carroll, A. R., Hendrix, M. S., Graham, S. A., Wartes, M. A., and Abbink, O. A., 2001. Sedimentary record of Mesozoic deformation and inception of the Turpan-Hami basin, northwest China. MEMOIRS-GEOLOGICAL SOCIETY OF AMERICA, 317-340.

He, B., Jiao, C., Xu, Z., Cai, Z., Zhang, J., Liu, S., Li, H., Chen, W., and Yu, Z., 2016. The paleotectonic and paleogeography reconstructions of the Tarim Basin and its adjacent areas (NW China) during the late Early and Middle Paleozoic. Gondwana Research, 30, 191-206.

Heilbronn, G., Boulvais, P., Marchand, E., Robin, C., Bourquin, S., Barrier, L., Jia, Y., Fu, B., Jolivet, M., 2015. Stable isotope characterization of pedogenic and lacustrine carbonates from the Chinese Tian Shan: Constraints on the Mesozoic-Lower Cenozoic palaeoenvironmental evolution. Chemie der Erde-Geochemistry, 75, (1), 133-141.

Hendrix, M. S., Graham, S. A., Carroll, A., Sobel, E., McKnight, C., Schulein, B., Wang, Z., 1992, Sedimentary record and climatic implications of recurrent deformation in the Tian Shan: evidence from Mesozoic strata of the north Tarim, south Dzungar, and Turpan basin, northwest China: Geological Society of America Bulletin, 104, 53-79. 
Hendrix, M. S., 2000. Evolution of Mesozoic sandstone compositions, southern Junggar, northern Tarim, and western Turpan basins, northwest China: a detrital record of the ancestral Tian Shan. Journal of Sedimentary Research, 70(3), 520-532.

Heermance, R. V., Chen, J., Burbank, D. W., Wang, C., 2007. Chronology and tectonic controls of Late Tertiary deposition in the southwestern Tian Shan foreland, NW China. Basin Research, 19(4), 599-632.

Heermance, R.V., Pearson, J., Moe, A., Langtao, L., Jianhong, X., Jie, C., Richter, F., Garzione, C.N., Junsheng, N., and Bogue, S., 2018, Erg deposition and development of the ancestral Taklimakan Desert (western China) between 12.2 and 7.0 Ma: Geology, 46, 919922 ,

Japsen, P., Green, P. F., Bonow, J. M., Nielsen, T. F., Chalmers, J. A., 2014. From volcanic plains to glaciated peaks: Burial, uplift and exhumation history of southern East Greenland after opening of the NE Atlantic. Global and Planetary Change, 116, 91-114.

Jenchuraeva, R., Bakirov, A., Ghes, M., Seltmann, R., Shatov, V., Popov, V., 2001. Mineral Deposits Map of Kyrgyzstan, 1:1,000,000. International Association on the Genesis of Ore Deposits, London-Bishkek.

Jin, Z., Yang, M., Lu, X., Sun, D., Tang, X., Peng, G., and Lei, G., 2008., The tectonics and petroleum system of the Qiulitagh fold and thrust belt, northern Tarim basin, NW China. Marine and Petroleum Geology, 25(8), 767-777.

Jolivet, M., Ritz, J. F., Vassallo, R., Larroque, C., Braucher, R., Todbileg, M., ... and Arzhanikova, A., 2007, Mongolian summits: an uplifted, flat, old but still preserved erosion surface: Geology, 35, (10), 871-874. 
Jolivet, M., Dominguez, S., Charreau, J., Chen, Y., Li, Y., and Wang, Q., 2010, Mesozoic and Cenozoic tectonic history of the Central Chinese Tian Shan: reactivated tectonic structures and active deformation: Tectonics, 29, TC 6019.

Jolivet, M., Arzhannikov, S., Arzhannikova, A., Chauvet, A., Vassallo, R., Braucher, R., 2013, Geomorphic Mesozoic and Cenozoic evolution in the Oka-Jombolok region (East Sayan ranges, Siberia): Journal of Asian Earth Sciences, 62, 117-133.

Jolivet, M., Bourquin, S., Heilbronn, G., Robin, C., Barrier, C., Dabard, M.-P., Jia, Y., De Pelsmaeker, E., Fu, B., 2017. The Upper Jurassic-Lower Cretaceous alluvial-fan deposits of the Kalaza Formation (Central Asia): tectonic pulse or increased aridity? In: Brunet, M.F., McCann, T. Sobel, E. R. (Eds.), Geological Evolution of Central Asian Basins and the Western Tien Shan Range. Geological Society, London, Special Publications, 427.

Jolivet, M., Barrier, L., Dauteuil, O., Laborde, A., Li, Q., Reichenbacher, B., ... and Guo, Z., 2018. Late Cretaceous-Palaeogene topography of the Chinese Tian Shan: New insights from geomorphology and sedimentology. Earth and Planetary Science Letters, 499, 95-106.

Jolivet, M., Boulvais, P., Barrier, L., Robin, C., Heilbronn, G., Ledoyen, J., ... and Bataleva, E., 2018b. Oxygen and Carbon Stable Isotope Composition of Cretaceous to Pliocene Calcareous Paleosols in the Tian Shan Region (Central Asia): Controlling Factors and Paleogeographic Implications. Geosciences, 8(9), 330.

Jourdon, A., Le Pourhiet, L., Petit, C., and Rolland, Y., 2017. The deep structure and reactivation of the Kyrgyz Tien Shan: Modelling the past to better constrain the present. Tectonophysics. 
Jourdon, A., Petit, C., Rolland, Y., Loury, C., Bellahsen, N., Guillot, S., ... \& Ganino, C., 2017. New structural data on Late Paleozoic tectonics in the Kyrgyz Tien Shan (Central Asian Orogenic Belt). Gondwana Research, 46, 57-78.

Jun, G., Maosong, L., Xuchang, X., Yaoqing, T., Guoqi, H., 1998. Paleozoic tectonic evolution of the Tianshan Orogen, northwestern China. Tectonophysics, 287, (1-4), 213-231.

Kapp, P., DeCelles, P. G., Gehrels, G. E., Heizler, M., Ding, L., 2007. Geological records of the Lhasa-Qiangtang and Indo-Asian collisions in the Nima area of central Tibet. Geological Society of America Bulletin, 119 (7-8), 917-933.

Kapp, P., Yin, A., Harrison, T. M., Ding, L., 2005, Cretaceous-Tertiary shortening, basin development, and volcanism in central Tibet: Geological Society of America Bulletin, 117, $865-878$.

Karpovitch, E.., Kolesnikov, V.A., Lunev, V.P., 1964. Geological map of the former USSR, 1:200 000 sheets. Alay-Kokshaal series K-43-XXVIII.

Kober, M., Seib, N., Kley, J., Voigt, T., 2013. Thick-skinned thrusting in the northern Tien Shan foreland, Kazakhstan: structural inheritance and polyphase deformation. Geological Society, London, Special Publications, 377, (1), 19-42.

Konopelko, D., Biske, G., Seltmann, R., Eklund, O., Belyatsky, B., 2007. Hercynian postcollisional A-type granites of the Kokshaal Range, southern Tien Shan, Kyrgyzstan. Lithos, 97(1-2), 140-160.

Kröner, A., Kovach, V., Alexeiev, D., Wang, K. L., Wong, J., Degtyarev, K., Kozakov, I., 2017. No excessive crustal growth in the Central Asian Orogenic Belt: Further evidence from field relationships and isotopic data. Gondwana Research, 50, 135-166. 
Lasovskiy A. G., Mozolev L. N., 1961. Geology map of USSR, sheet K 43-XXI, scale 1:200 000, Northern Tian-Shan series.

Li, B., Zhuang, X., Li, J., Zhao, S., 2014. Geological controls on coal quality of the Yili Basin, Xinjiang Northwest China. International Journal of Coal Geology, 131, 186-199.

Li, D., He, D., Tang, Y., Wu, X., Lian, Y., Yang, Y., 2015. Dynamic processes from plate subduction to intracontinental deformation: Insights from the tectono-sedimentary evolution of the Zhaosu-Tekesi Depression in the southwestern Chinese Tianshan. Journal of Asian Earth Sciences, 113, 728-747

Lin, C., Yang, H., Liu, J., Rui, Z., Cai, Z., Zhu, Y., 2012. Distribution and erosion of the Paleozoic tectonic unconformities in the Tarim Basin, Northwest China: significance for the evolution of paleo-uplifts and tectonic geography during deformation. Journal of Asian Earth Sciences, 46, 1-19.

Liu, H., Somerville, I. D., Lin, C., Zuo, S., 2016. Distribution of Palaeozoic tectonic superimposed unconformities in the Tarim Basin, NW China: significance for the evolution of palaeogeomorphology and sedimentary response. Geological Journal, 51(4), 627-651.

Lucas, S. G., Bayshashov, B. U., Tyutkova, L. A., Zhamangara, A. K., Aubekerov, B. Z., 1997. Mammalian biochronology of the Paleogene-Neogene boundary at Aktau Mountain, eastern Kazakhstan. Palaontologische Zeitschrift, 71, 305-314.

Lucas, S. G., Aubekerov, B. Z., Dzhamangaraeva, A. K., Bayshashov, B. U., Tyutkova, L. A., 2000. Cenozoic lacustrine deposits of the Ili Basin, southeastern Kazakhstan. In: Kelts, K. R. (ed.) Lake Basins Through Space and Time. American Association of Petroleum Geologists, Tulsa, 59-64. 
Macaulay, E. A., Sobel, E. R., Mikolaichuk, A., Kohn, B., Stuart, F. M., 2014. Cenozoic deformation and exhumation history of the Central Kyrgyz Tien Shan. Tectonics, 33, (2), 135165.

Métivier, F., and Gaudemer, Y., 1997. Mass transfer between eastern Tien Shan and adjacent basins (central Asia): constraints on regional tectonics and topography. Geophysical Journal International, 128(1), 1-17.

Morin, J., Jolivet, M., Robin, C., Heilbronn, G., Barrier, L., Bourquin, S., Jia, Y., 2018. Jurassic paleogeography of the Tian Shan: An evolution driven by far-field tectonics and climate. Earth-Science Reviews, 187, 286-313.

Peulvast, J. P., and Claudino Sales, V., 2005. Surfaces d'aplanissement et géodynamique. Géomorphologie: relief, processus, environnement, 11, (4), 249-274.

Reiners, P. W., and Brandon, M. T., 2006. Using thermochronology to understand orogenic erosion. Annu. Rev. Earth Planet. Sci., 34, 419-466.

Roger, F., Jolivet, M., and Malavieille, J., 2010, The tectonic evolution of the Songpan-Garzê (North Tibet) and adjacent areas from Proterozoic to Present: A synthesis: Journal of Asian Earth Sciences, 39, 254-269.

Shao, L., Stattegger, K., Li, W., Haupt, B. J., 1999. Depositional style and subsidence history of the Turpan Basin (NW China). Sedimentary Geology, 128, 155-169.

Shao, L., Zhang, P., Hilton, J., Gayer, R., Wang, Y., Zhao, C., Luo, Zh., 2003. Palaeoenvironments and Palaeogeography of the Lower and lower Middle Jurassic coal measures in the Turpan-Hami oil-prone coal basin, northwestern China. American Association of Petroleum Geology Bulletin, 87, 335-355. 
Sobel, E. R., Oskin, M., Burbank, D., Mikolaichuk, A., 2006a. Exhumation of basement- cored uplifts: Example of the Kyrgyz Range quantified with apatite fission track thermochronology. Tectonics, 25(2).

Sobel, E.R., Chen, J., Heermance, R.V., 2006b, Late Oligocene - Early Miocene initiation of shortening in the Southwestern Chinese Tian Shan: implications for Neogene shortening rate variations: Earth and Planetary Science Letters, 247, 70-81.

Tang, F., Luo, Z.X., Zhou, Z.H., You, H.L., Georgi, J.A., Tang, Z.L., Wang, X.Z., 2001, Biostratigraphy and palaeoenvironment of the dinosaur-bearing sediments in Lower Cretaceous of Mazongshan area, Gansu Province, China: Cretaceous Research, 22, 115-129.

Tang, W., Zhang, Z., Li, J., Li, K., Luo, Z., Chen, Y., 2015. Mesozoic and Cenozoic uplift and exhumation of the Bogda Mountain, NW China: Evidence from apatite fission track analysis. Geoscience Frontiers, 6(4), 617-625.

Tapponnier, P., and Molnar, P., 1979. Active faulting and Cenozoic tectonics of the Tien Shan, Mongolia, and Baykal regions. Journal of Geophysical Research: Solid Earth, 84(B7), 3425-3459.

Turner, S. A., Cosgrove, J. W., and Liu, J. G., 2010. Controls on lateral structural variability along the Keping Shan Thrust Belt, SW Tien Shan Foreland, China. Geological Society, London, Special Publications, 348(1), 71-85.

Tursungaziev, B.T., Petrov, O.B., 2008. Geological map of the Kyrgyz Republic, 1:500,000. Agency of Geology and Mineralogical Resources of the Kyrgyz Republic, Bishkek. 
Vincent, S. J., and Allen, M. B., 2001. Sedimentary record of Mesozoic intracontinental deformation in the eastern Junggar Basin, northwest China: response to orogeny at the Asian margin. Memoirs-Geological Society of America, 341-360.

VNIGNI and Beicip Franlab., 1992. Petroleum potential of Central Asia, 2 volumes, Beicip Franlab, Rueil-Malmaison, France.

Wang, J., Wang, H., Chen, H., Jiang, S., and Zhao, S. E., 2013. Responses of two lithosomes of Lower Cretaceous coarse clastic rocks to tectonism in Kuqa foreland sub-basin, Northern Tarim Basin, Northwest China. Sedimentary Geology, 289, 182-193.

Wei, H. H., Meng, Q. R., Ding, L., and Li, Z. Y., 2013. Tertiary evolution of the western Tarim basin, northwest China: A tectono- sedimentary response to northward indentation of the Pamir salient. Tectonics, 32(3), 558-575.

Widdowson, M., 1997. The geomorphological and geological importance of palaeosurfaces. In: Widdowson, M. (Ed.), Palaeosurfaces: Recognition, Reconstruction and Palaeoenvironmental Interpretation. Geological Society Special Publication, London, 1-12.

Wilhem, C., Windley, B. F., Stampfli, G. M., 2012. The Altaids of Central Asia: a tectonic and evolutionary innovative review. Earth-Science Reviews, 113, (3-4), 303-341.

Windley, B. F., Allen, M. B., Zhang, C., Zhao, Z. Y., Wang, G. R., 1990. Paleozoic accretion and Cenozoic redeformation of the Chinese Tien Shan range, central Asia. Geology, 18(2), 128-131.

Windley, B. F., Alexeiev, D., Xiao, W., Kröner, A., Badarch, G., 2007. Tectonic models for accretion of the Central Asian Orogenic Belt. Journal of the Geological Society, 164(1), 3147. 
Xiao, W., Windley, B. F., Allen, M. B., Han, C., 2013. Paleozoic multiple accretionary and collisional tectonics of the Chinese Tianshan orogenic collage. Gondwana Research, 23(4), 1316-1341.

Xinjiang Bureau of Geology and Mineral Resources (XBGMR), Geological maps of the eastern Yili area, scale 1:200,000, Geol. Publ. House, Beijing (1973).

Yang, Y., and Liu, M., 2002. Cenozoic deformation of the Tarim plate and the implications for mountain building in the Tibetan Plateau and the Tian Shan. Tectonics, 21(6).

Yang, W., Jolivet, M., Dupont-Nivet, G., Guo, Z., Zhang, Z., Zhang, Z., 2013. Source to sink relations between the Tian Shan and Junggar Basin (northwest China) from Late Palaeozoic to Quaternary: evidence from detrital U-Pb zircon geochronology. Basin Research, 25, 219-240.

Yang, Y.-T., Song, C.-C., He, S., 2015. Jurassic tectonostratigraphic evolution of the Junggar basin, NW China: A record of Mesozoic intraplate deformation in Central Asia. Tectonics, 34, 86-115.

Yin, A., Nie, S., Craig, P., Harrison, T. M., Ryerson, F. J., Xianglin, Q., and Geng, Y., 1998. Late Cenozoic tectonic evolution of the southern Chinese Tian Shan. Tectonics, 17(1), 1-27.

Zhang, C. L., Zou, H. B., Li, H. K., and Wang, H. Y., 2013. Tectonic framework and evolution of the Tarim Block in NW China. Gondwana Research, 23(4), 1306-1315.

\section{Figure captions}

Fig. 1: General topographic and structural map of the Tian Shan region showing the main dataset used in this study; Bay. B: Bayanbulak Basin; M-K: Ming-Kush Basin; S-K: SongKul; NTSF: North Tian Shan Fault; NL: Nikolaev Line; TFF: Talas Fergana Fault. 
Fig. 2: Example of data used in this study to identify, localize and characterize the planation surfaces visible in the Tian Shan Range. A. SRTM-derived DEM of the Song-Kul region; B. Simplified geological maps of the Song-Kul region. C. SRTM-derived slope map showing the steep relief (blue) and highlighting the low-relief areas (yellow) within the Song-Kul region. D. Field picture illustrating the morphology of a planation surface visible within this region. E. Topographic cross-sections across the Song-Kul region showing the main planation surfaces visible within this area.

Fig. 3: Schematic Temperature/Time evolution in both ranges and basins illustrating the general implication of such path in term of relief and stratigraphy.

Fig. 4: General topographic and structural map of the Tian Shan showing the main planation surfaces visible within this area and interpreted swath profiles (tectonic structures inferred from Charvet et al., 2011; Jourdon et al., 2017). ; Bay. B: Bayanbulak Basin; M-K: MingKush Basin; S-K: Song-Kul; N.L: Nikolaev Line; TFF: Talas Fergana Fault.

Fig. 5: Synthetic chart of the Tian Shan region compiling available stratigraphic and lowthermochronology data (based on bibliographic synthesis, references on the figure).

Fig. 6: Field pictures presenting of the tilted planation surfaces visible within the Naryn region.

Fig. 7: Slope map of the Aktau Range highlighting the presence of perched low-relief surfaces within this region.

Fig. 8. Field pictures presenting the different morphologies of the planation surfaces visible within the Yili region topography. 
Fig. 9: Slope map and satellite image of Bayanbulak region illustrating the different morphologies of the planation surfaces visible in this area.

Fig. 10: 3D digital elevation model of the Bogda Shan Range showing the high range lying about 1000 to $1500 \mathrm{~m}$ above the Mesozoic planation surface (see Fig. 2 for location).

Fig.11: Structure and regional unconformities in the eastern Tarim Basin. A and B. Northsouth interpreted seismic profiles through the eastern Tarim Basin (see Fig. 1 for location). A. 1, A. 2, B. 1 and B. 2. Details of the interpreted seismic profiles showing the different erosional surfaces in the eastern Tarim Basin and their geometrical relationships. Red arrows represent reflector terminations (onlap, toplap). The A. 2. seismic profile detail shows the two distinct morphologies of the erosional surface separated by a Mesozoic reverse fault.

Fig. 12: Ages of the planation surfaces in regard to climate and geodynamic events. Relative chronology inferred from a synthetize of available data on the Tian Shan region and from geomorphological observations. Climate inferred from Hendrix et al. (1992). 


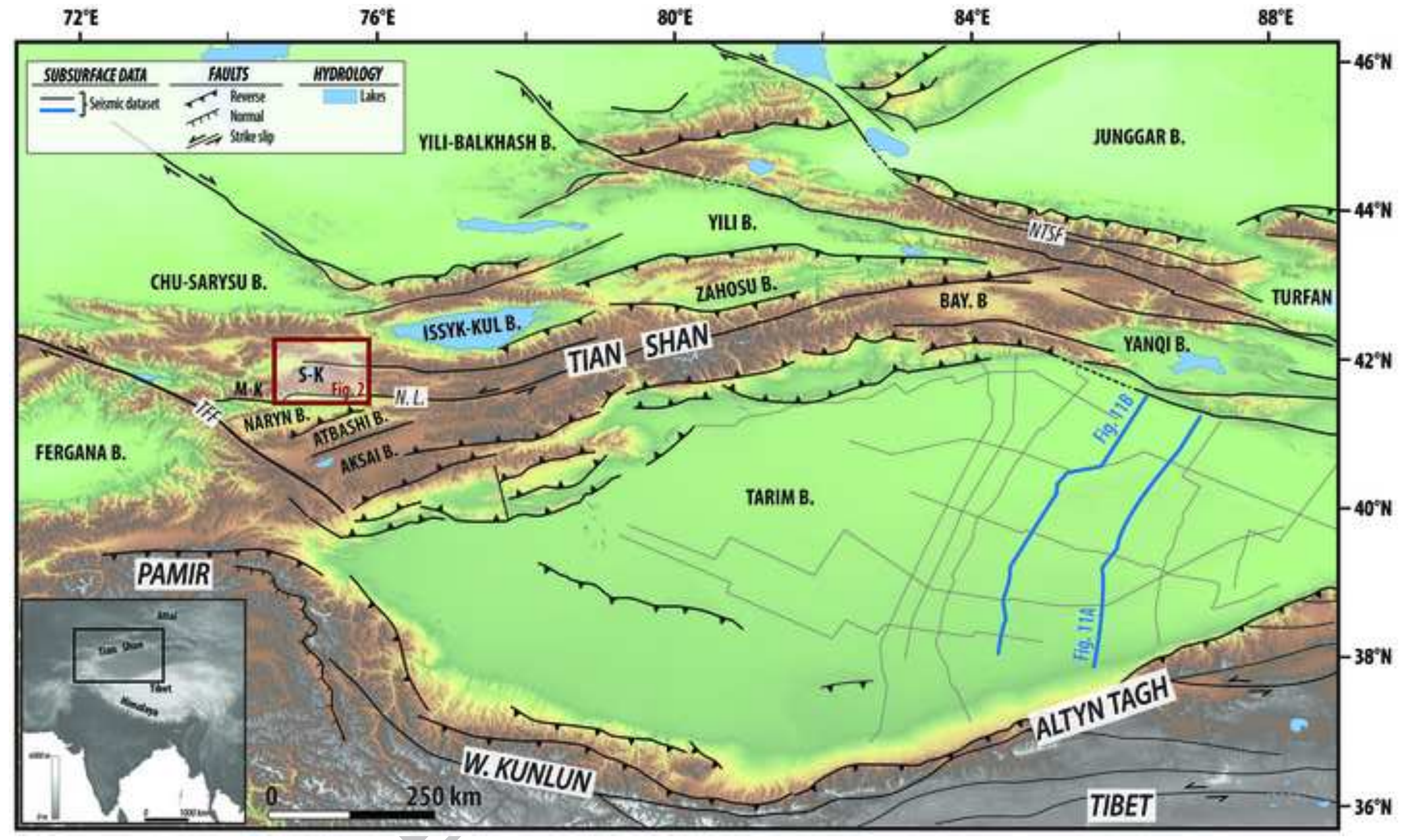



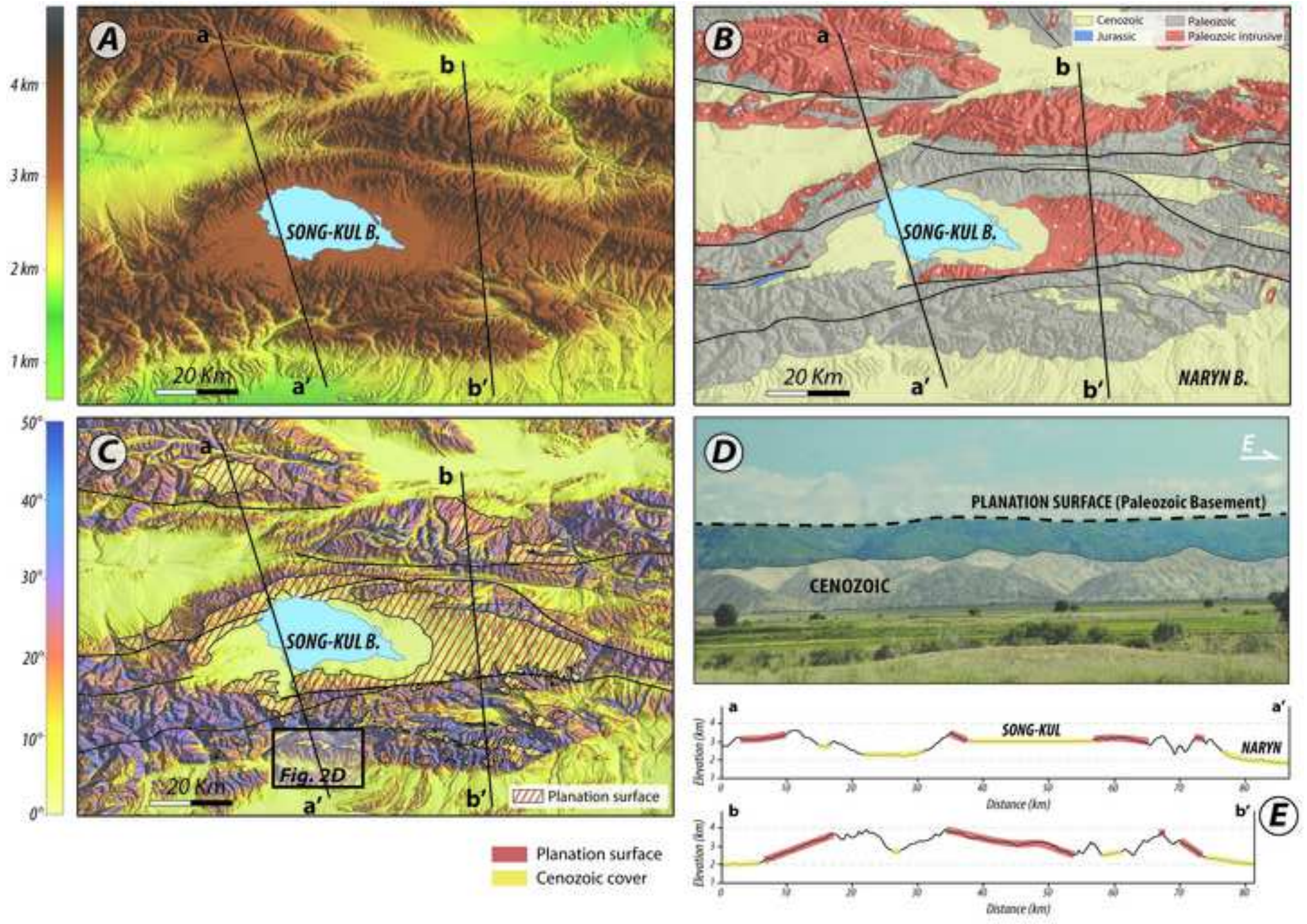

Planation surface Cenozoic cover 


\section{ACCEPTED MANUSCRIPT}

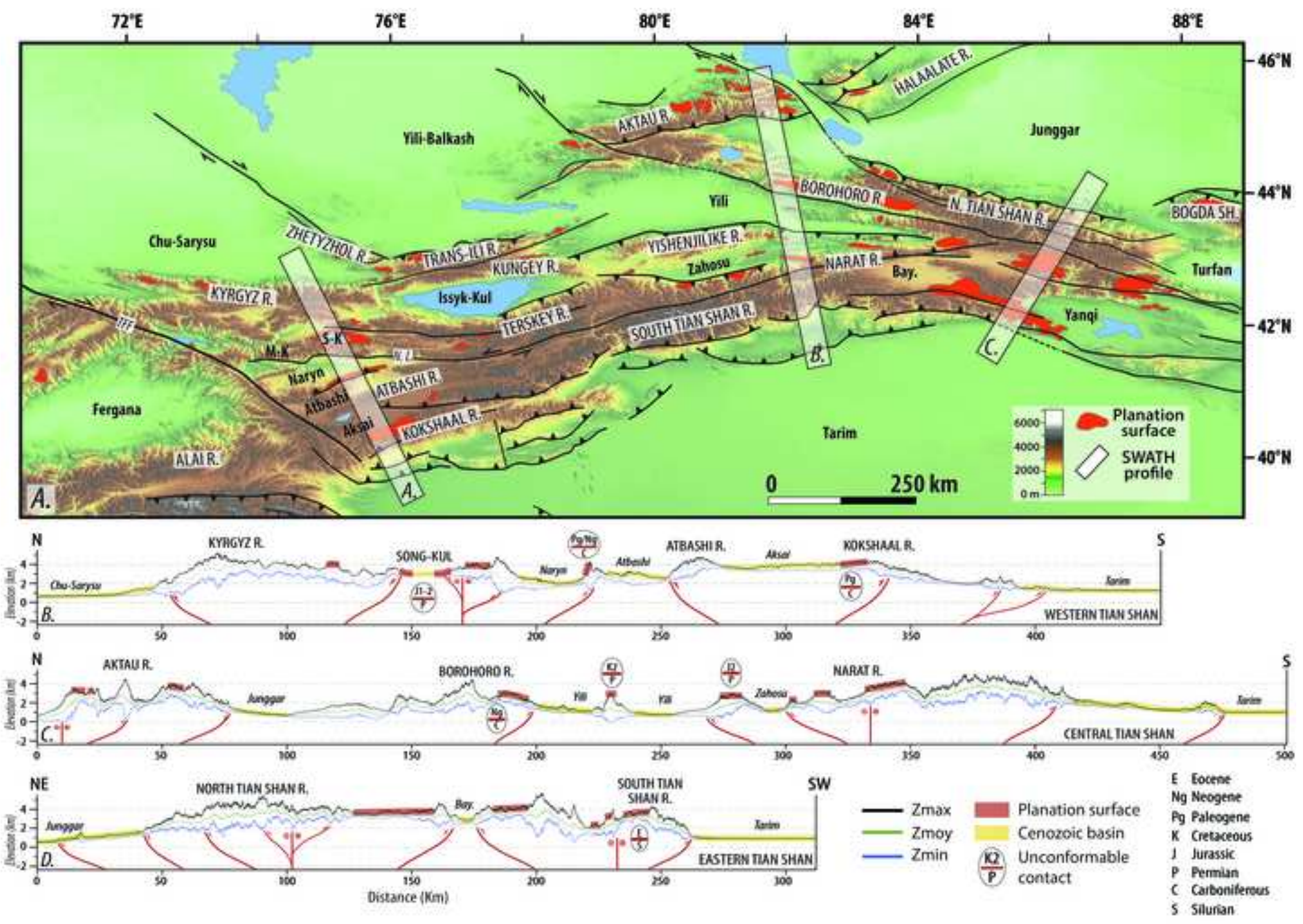




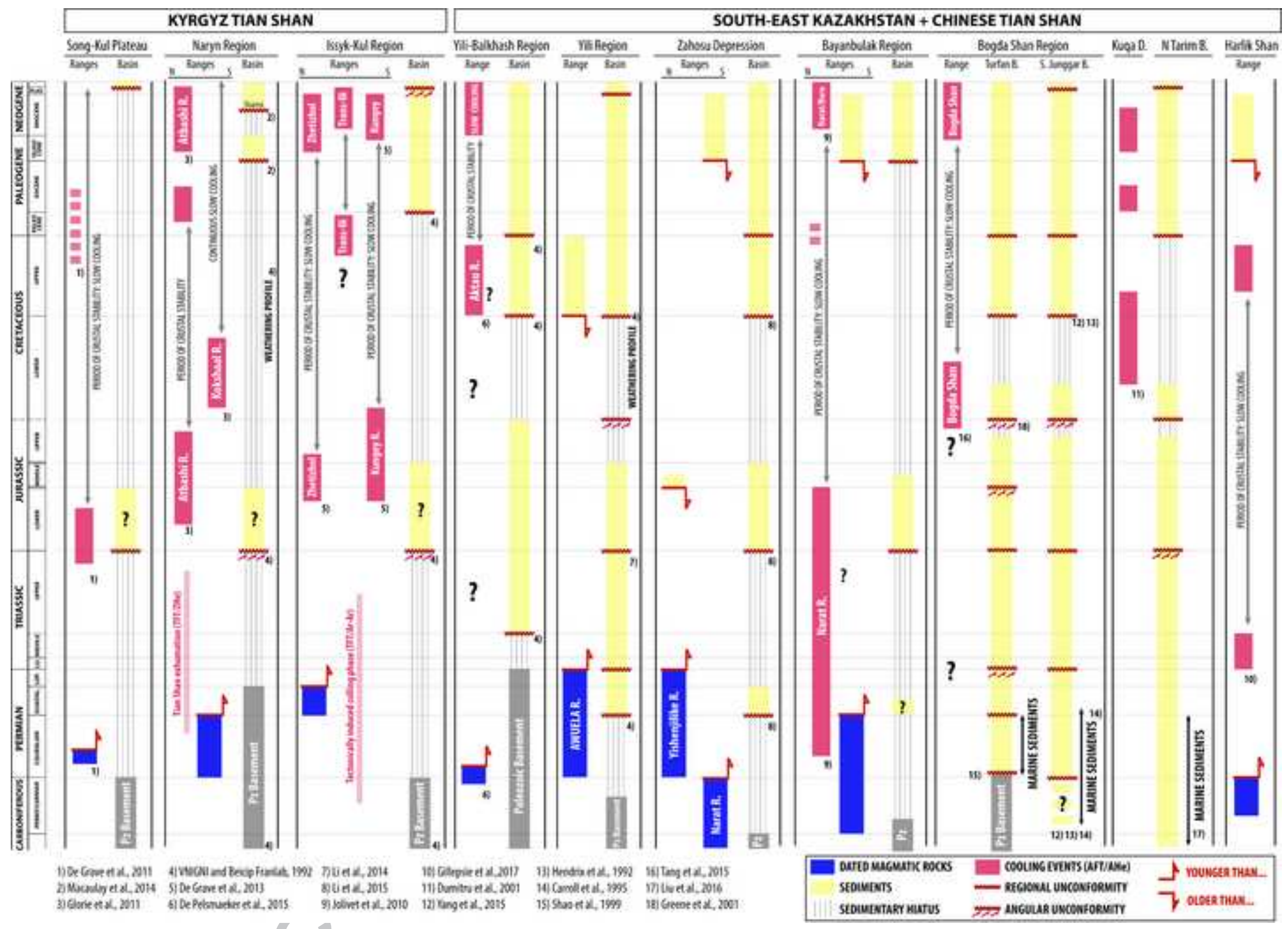


Karatoo Range (Naryn region)

N41.225\% E75. $25^{\circ}$

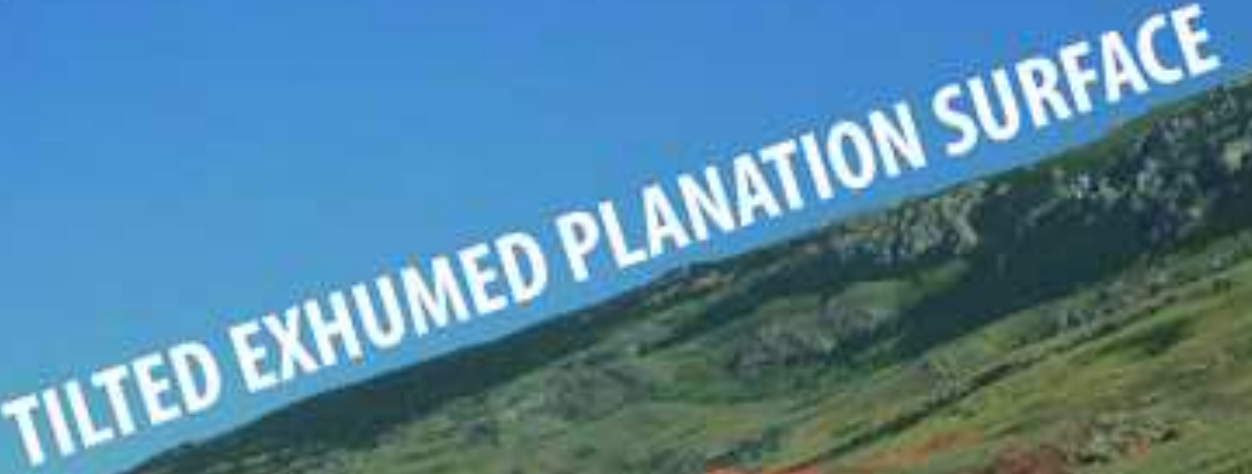

ShamsiFm.

(NEOGENE)
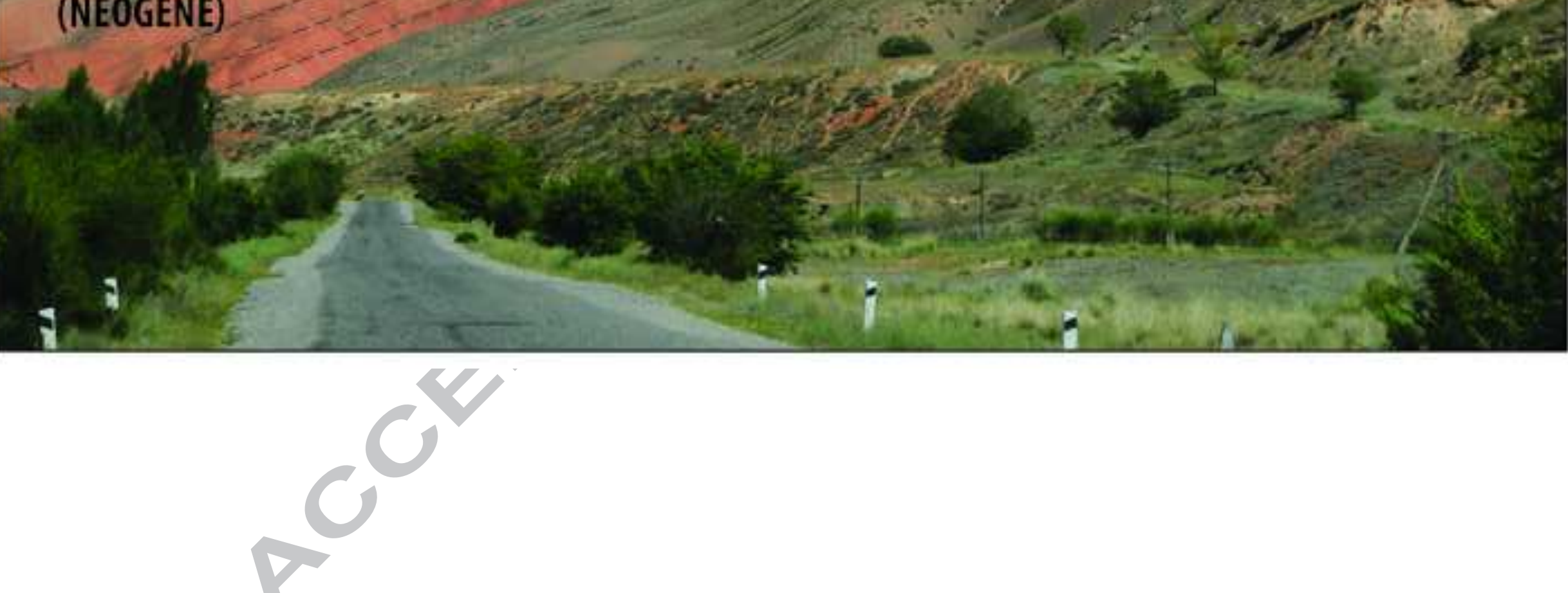


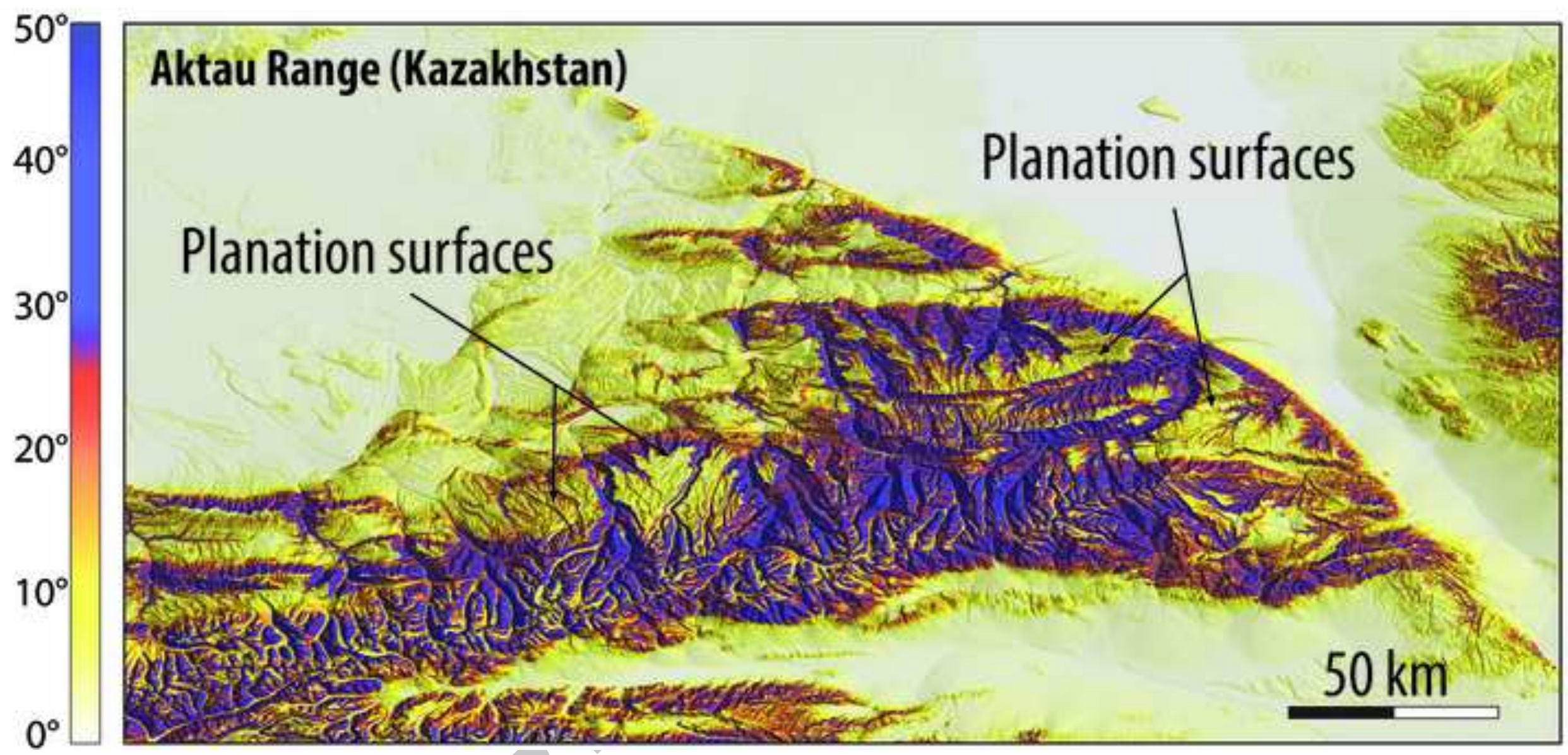



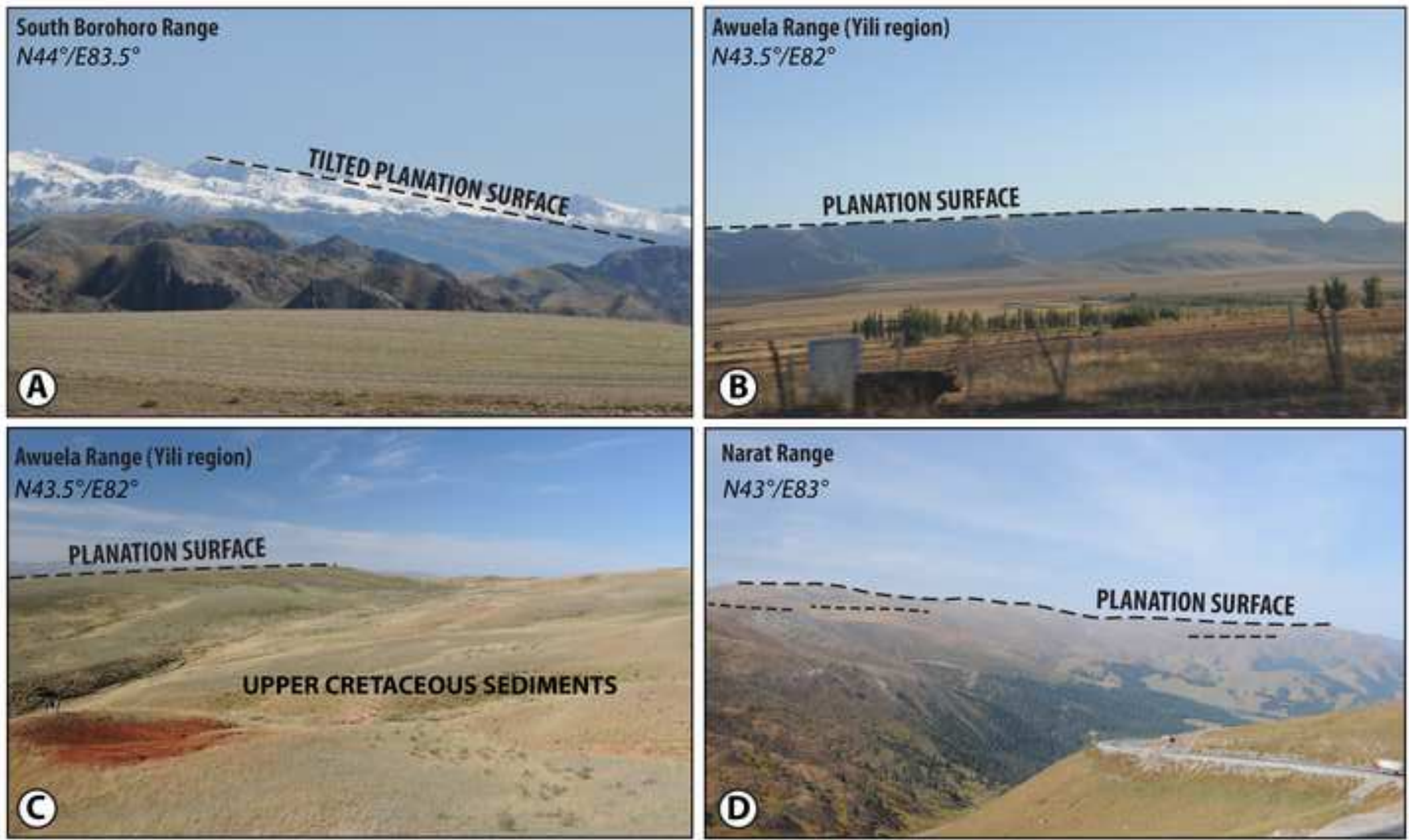

\section{Narat Range}

$\mathrm{N} 43^{\circ} / \mathrm{E}^{\circ} 3^{\circ}$

(D)

PLANATION SURFACE

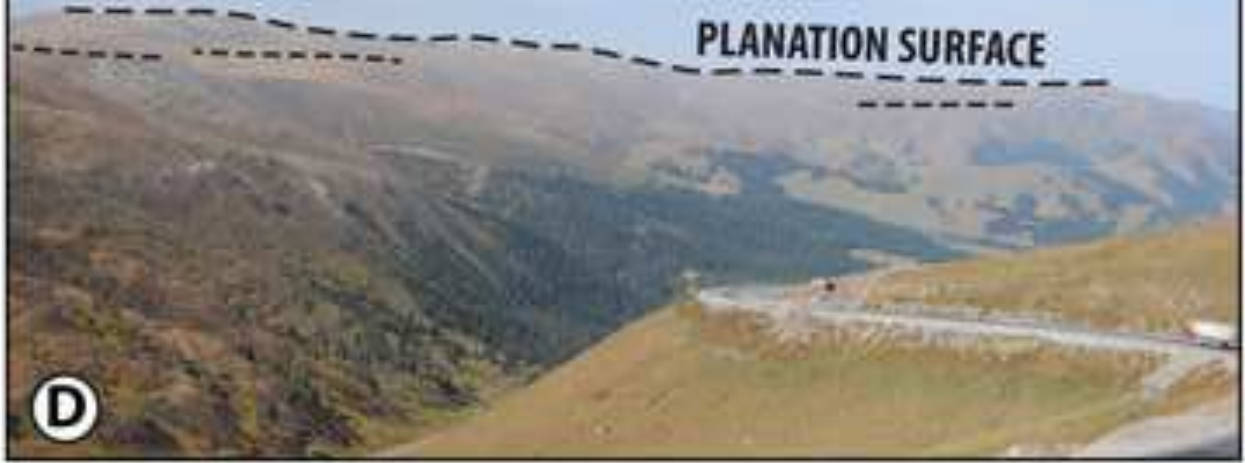



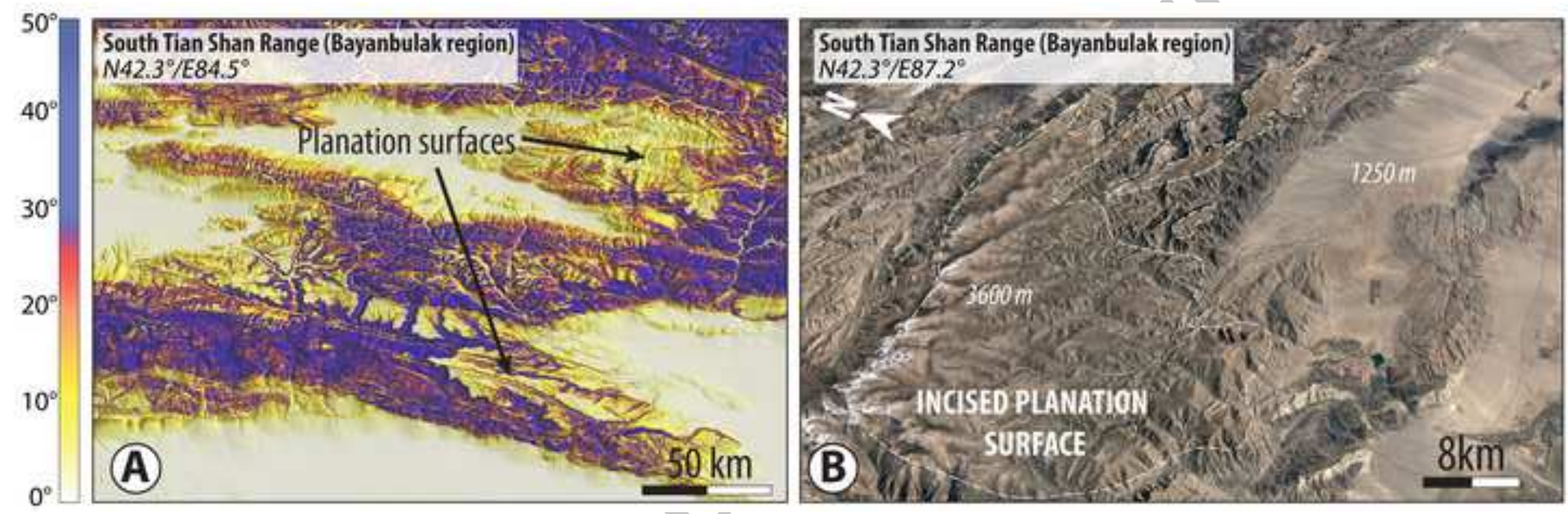


\section{ACCEPTED MANUSCRIPT}

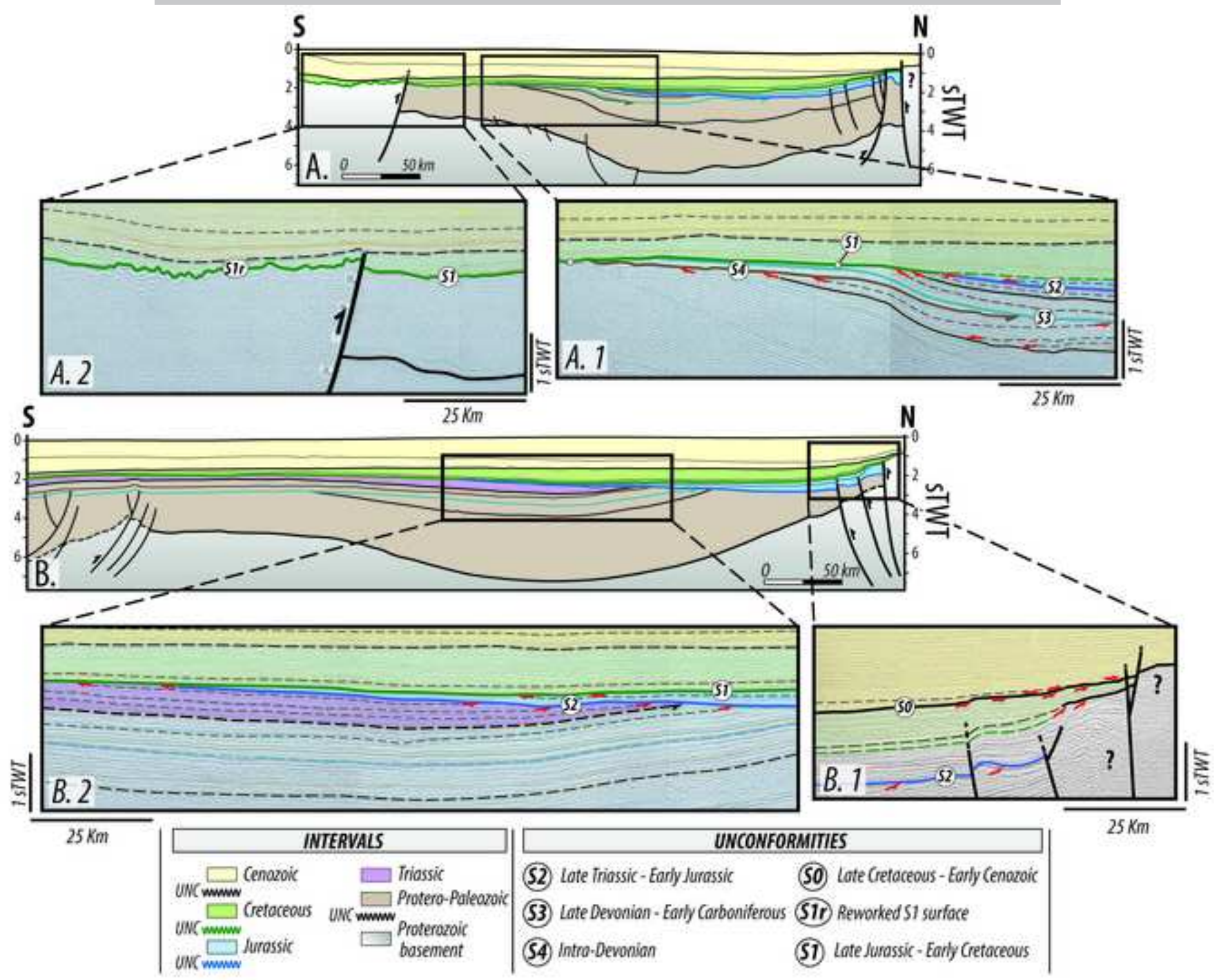




\section{PLANATION SURFACES}

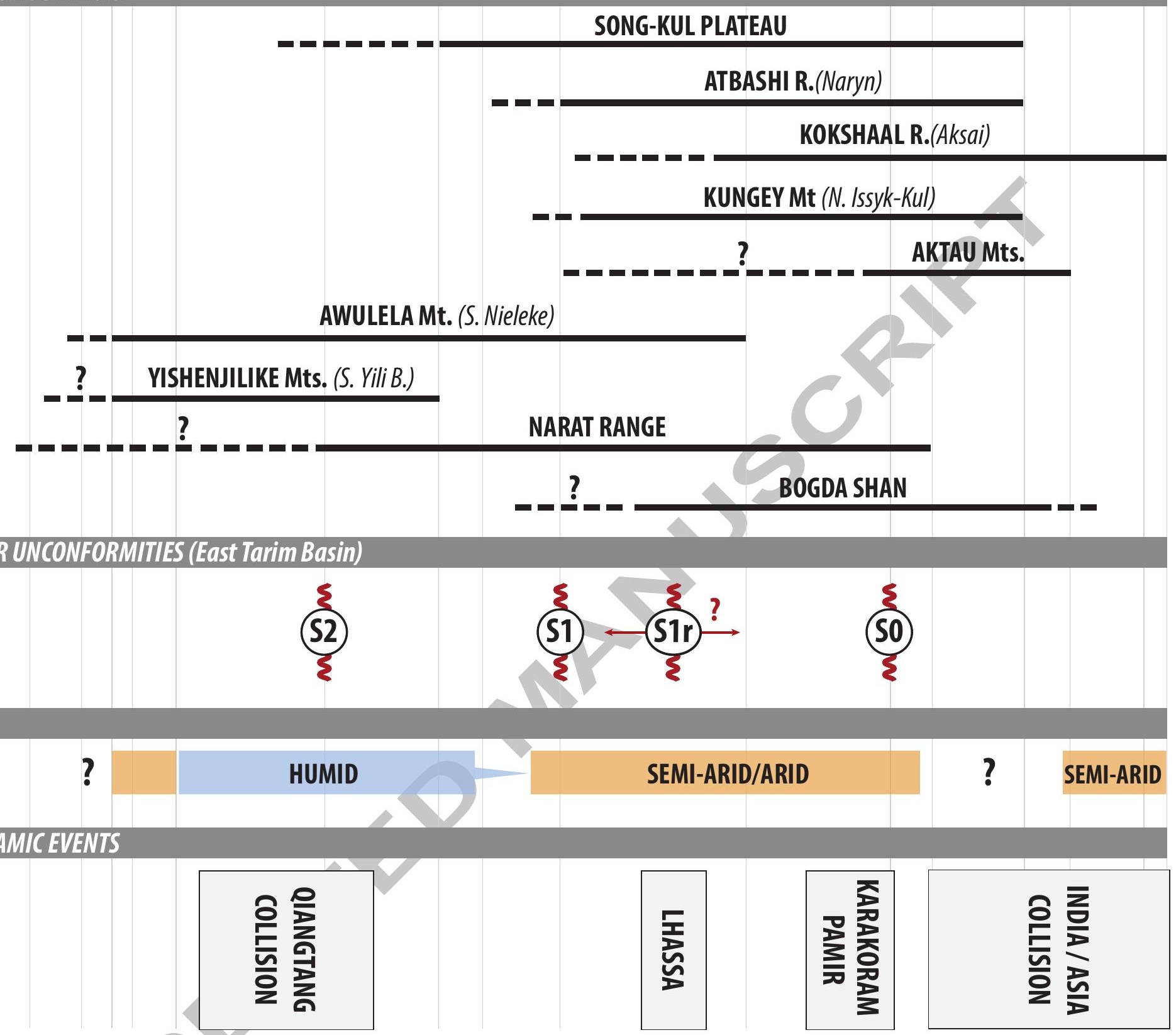

\section{CLIMATE}

\section{ANGULAR UNCONFORMITIES (East Tarim Basin)}

\begin{tabular}{|c|c|}
\hline$?$ & HUMID \\
\hline \multicolumn{2}{|l|}{ GEODYNAMIC EVENTS } \\
\hline & 을 을 \\
\hline
\end{tabular}

空


Graphical abstract

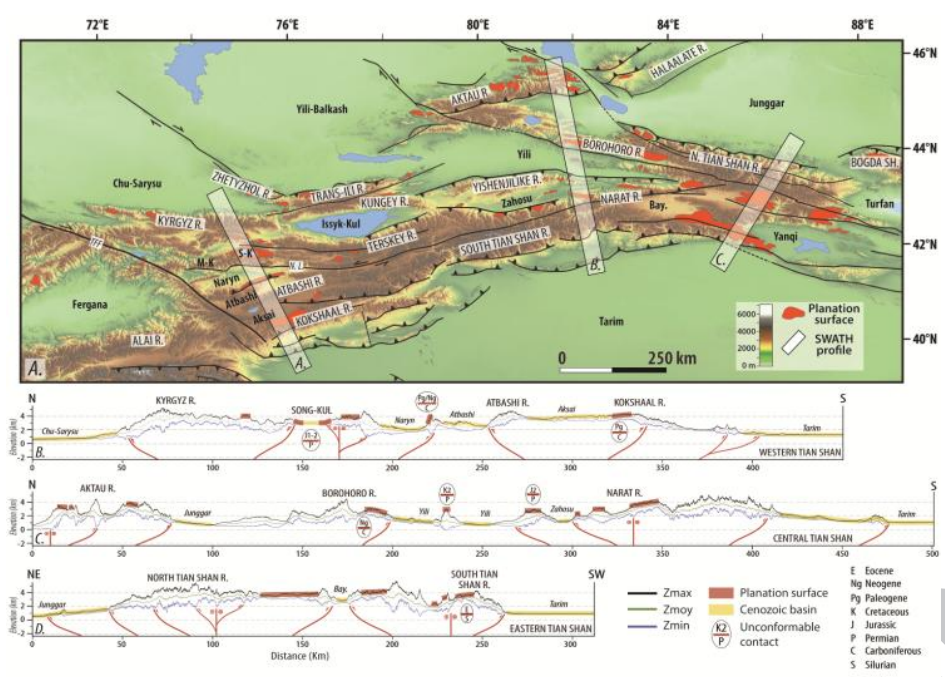




\section{HIGHLIGHTS}

- Different generation of surfaces are preserved within the Tian Shan Range

- These erosion events span from the late Paleozoic to the Early Cenozoic

- This region did not undergo strong relief building during most of the Mesozoic

- The Tian Shan topography was in a strong non-equilibrium state during the Cenozoic 